Validation of the Predicted Circumferential and Radial Mode Sound Power Levels in the Inlet and Exhaust Ducts of a Fan Ingesting Distorted Inflow

\author{
L. Danielle Koch
}

Glenn Research Center, Cleveland, Ohio 


\section{NASA STI Program . . . in Profile}

Since its founding, NASA has been dedicated to the advancement of aeronautics and space science. The NASA Scientific and Technical Information (STI) program plays a key part in helping NASA maintain this important role.

The NASA STI Program operates under the auspices of the Agency Chief Information Officer. It collects, organizes, provides for archiving, and disseminates NASA's STI. The NASA STI program provides access to the NASA Aeronautics and Space Database and its public interface, the NASA Technical Reports Server, thus providing one of the largest collections of aeronautical and space science STI in the world. Results are published in both non-NASA channels and by NASA in the NASA STI Report Series, which includes the following report types:

- TECHNICAL PUBLICATION. Reports of completed research or a major significant phase of research that present the results of NASA programs and include extensive data or theoretical analysis. Includes compilations of significant scientific and technical data and information deemed to be of continuing reference value. NASA counterpart of peer-reviewed formal professional papers but has less stringent limitations on manuscript length and extent of graphic presentations.

- TECHNICAL MEMORANDUM. Scientific and technical findings that are preliminary or of specialized interest, e.g., quick release reports, working papers, and bibliographies that contain minimal annotation. Does not contain extensive analysis.

- CONTRACTOR REPORT. Scientific and technical findings by NASA-sponsored contractors and grantees.
- CONFERENCE PUBLICATION. Collected papers from scientific and technical conferences, symposia, seminars, or other meetings sponsored or cosponsored by NASA.

- SPECIAL PUBLICATION. Scientific, technical, or historical information from NASA programs, projects, and missions, often concerned with subjects having substantial public interest.

- TECHNICAL TRANSLATION. Englishlanguage translations of foreign scientific and technical material pertinent to NASA's mission.

Specialized services also include creating custom thesauri, building customized databases, organizing and publishing research results.

For more information about the NASA STI program, see the following:

- Access the NASA STI program home page at http://www.sti.nasa.gov

- E-mail your question via the Internet to help@ sti.nasa.gov

- Fax your question to the NASA STI Help Desk at $443-757-5803$

- Telephone the NASA STI Help Desk at 443-757-5802

- Write to: NASA Center for AeroSpace Information (CASI) 7115 Standard Drive Hanover, MD 21076-1320 


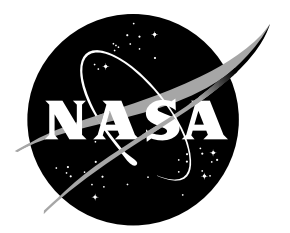

\section{Validation of the Predicted Circumferential and Radial Mode Sound Power Levels in the Inlet and Exhaust Ducts of a Fan Ingesting Distorted Inflow}

\section{Danielle Koch}

Glenn Research Center, Cleveland, Ohio

Prepared for the

17th Aeroacoustics Conference

cosponsored by the American Institute of Aeronautics and Astronautics and the Confederation of European Aerospace Societies

Portland, Oregon, June 5-8, 2011

National Aeronautics and

Space Administration

Glenn Research Center

Cleveland, Ohio 44135 


\section{Acknowledgments}

I would like to thank the AAPL staff for their work obtaining the experimental data. I also appreciate the insight that my colleagues Ed Envia, Dan Sutliff, Brenda Henderson and Ray Hixon shared along the way. Funding for this research has been provided by the Subsonic Fixed Wing Project which is a part of NASA's Fundamental Aeronautics Program.

This work was sponsored by the Fundamental Aeronautics Program at the NASA Glenn Research Center.

Level of Review: This material has been technically reviewed by technical management.

Available from

NASA Center for Aerospace Information 7115 Standard Drive

Hanover, MD 21076-1320
National Technical Information Service 5301 Shawnee Road Alexandria, VA 22312

Available electronically at http://www.sti.nasa.gov 


\title{
Validation of the Predicted Circumferential and Radial Mode Sound Power Levels in the Inlet and Exhaust Ducts of a Fan Ingesting Distorted Inflow
}

\author{
L. Danielle Koch \\ National Aeronautics and Space Administration \\ Glenn Research Center \\ Cleveland, Ohio 44135
}

\begin{abstract}
Fan inflow distortion tone noise has been studied computationally and experimentally. Data from two experiments in the NASA Glenn Advanced Noise Control Fan rig have been used to validate acoustic predictions. The inflow to the fan was distorted by cylindrical rods inserted radially into the inlet duct one rotor chord length upstream of the fan. The rods were arranged in both symmetric and asymmetric circumferential patterns. In-duct and farfield sound pressure level measurements were recorded. It was discovered that for positive circumferential modes, measured circumferential mode sound power levels in the exhaust duct were greater than those in the inlet duct and for negative circumferential modes, measured total circumferential mode sound power levels in the exhaust were less than those in the inlet. Predicted trends in overall sound power level were proven to be useful in indentifying circumferentially asymmetric distortion patterns that reduce overall inlet distortion tone noise, as compared to symmetric arrangements of rods. Detailed comparisons between the measured and predicted radial mode sound power in the inlet and exhaust duct indicate limitations of the theory.
\end{abstract}

\section{Nomenclature}

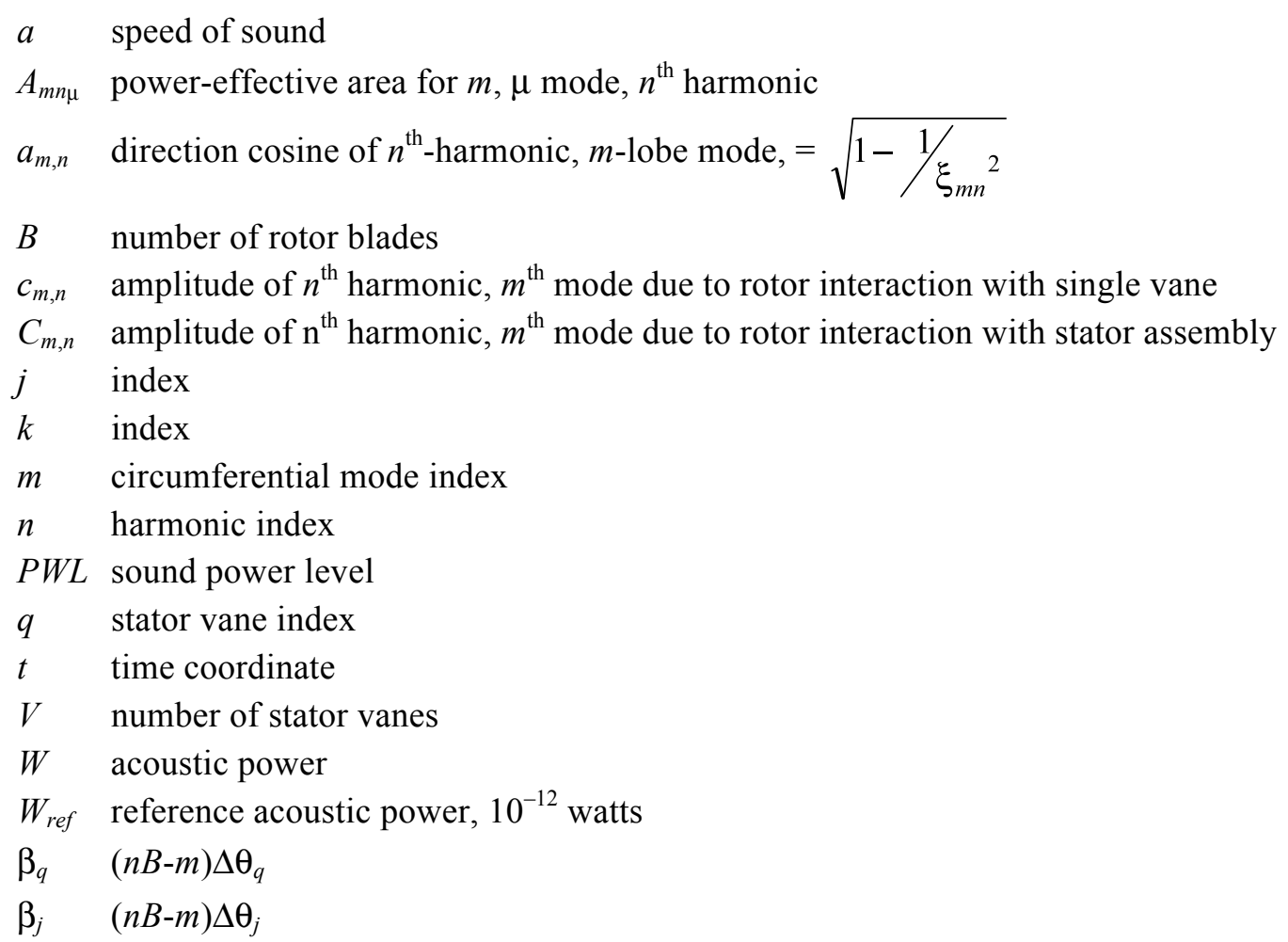


$\mu \quad$ radial mode index

$\xi_{m n} \quad$ cutoff ratio of $m$-lobe mode, $n^{\text {th }}$ harmonic

$\rho$ density

* complex conjugate

\subsection{Introduction}

Tone noise produced when a fan ingests distorted inflow is a problem for fans of all sizes - from the large fans featured in embedded aircraft engine concepts (Ref. 1) to the small fans in spacecraft ventilation systems (Ref. 2). In order to develop fan systems that minimize fan tone noise, design engineers need to be able to compute tone power levels for realistic models of the fan and duct. With acoustic prediction tools, different fan and duct geometries can be evaluated for acoustic performance early in the design cycle, which can ultimately lead to quieter final products. Several tone noise prediction methods are currently under development at NASA Glenn. Experiments in the NASA Glenn Advanced Noise Control Fan (ANCF) rig are currently being used to validate predicted results and gain a fundamental understanding of the physics of inlet distortion fan tone noise.

Reference 3 presents a method for computing circumferential mode sound power levels of a fan ingesting distorted inflow. In this model, it was assumed that only the first radial mode contributes to each propagating circumferential mode. Sound power levels in the inlet and exhaust duct were assumed to be equal to the value calculated at the generation plane (the rotor leading edge), and the overall sound power level computed from their sum. Data from an experiment conducted in the ANCF in 2007 were used to validate those predictions.

That prediction method and the associated set of assumptions (Ref. 3 ) were used to design a second inlet distortion test for the ANCF that was conducted in 2010. Like the 2007 experiment, the 2010 inlet distortion test used cylindrical rods inserted radially into the duct upstream of the fan to distort the inflow. The purpose of the 2010 inlet distortion test was to determine if predictions could be used to select circumferentially asymmetric distortion patterns that would reduce overall inlet distortion tone noise, as compared to symmetric arrangements of rods. The 2010 experimental results indicate that predictions assuming that only the first radial mode propagates, and that the inlet and exhaust sound power levels were equal to the value calculated at the generation plane (rotor leading edge), were in fact useful in identifying overall quieter configurations.

Finally, the theory was applied to estimate the sound power levels at the inlet and exhaust planes. Instead of simply neglecting the contribution from all but the first radial mode, predictions for all propagating radial modes were made by assuming that the model for the unsteady pressure distribution at the interaction plane was constant for all radial modes. These estimations are compared to data from both the 2007 and the 2010 experiments, and strengths and weaknesses of the prediction method are discussed.

Insight from this work is being used to develop a tone noise prediction code capable of estimating both circumferential and radial sound power levels based on the methodology used in the V072 Rotor/Stator Interaction Code (Ref. 4) for more realistic models of the fan geometry.

\subsection{Experiments}

Two fan inlet distortion experiments were conducted in 2007 and 2010 using the NASA Glenn Advanced Noise Control Fan that is housed within AeroAcoustic Propulsion Laboratory (AAPL). The ANCF, shown in Figure 1, is $1.2 \mathrm{~m}$ (48 in.) in diameter and the centerline of the fan is $3.0 \mathrm{~m}(10 \mathrm{ft})$ above the floor. For both tests, no stator vanes were installed downstream of the rotor. The rotor had 16 blades set at a $28^{\circ}$ pitch angle for all test conditions. 
An Inflow Control Device (ICD) was used to condition the flow entering the fan, removing largescale turbulence and ground vortices. The inlet plane was located $0.920 \mathrm{~m}(36.2 \mathrm{in}$.) or approximately $0.750 \mathrm{~L} / \mathrm{D}$ ahead of the leading edge of the fan at the tip location. The exhaust plane was located $1.20 \mathrm{~m}$ (45.4 in.) or approximately 1.0 L/D downstream of the trailing edge of the fan at the tip location. Downstream of the test section, the centerbody diameter increases to $0.710 \mathrm{~m} \mathrm{(24.0} \mathrm{in.)} \mathrm{to} \mathrm{mimic} \mathrm{a} \mathrm{nozzle}$ area contraction, yielding a hub-to-tip ratio of, $\sigma=0.500$. The hub diameter at the rotor leading edge was $0.460 \mathrm{~m}$ (18.0 in.), yielding a hub-to-tip ratio of, $\sigma=0.375$.

The inflow to the rotor was distorted by installing smooth cylindrical rods upstream of the rotor, as shown in Figure 2. The rods were $1.27 \mathrm{~cm}$ (0.500 in.) in diameter and were $31.8 \mathrm{~cm}$ (12.5 in.) long, resulting in a $6.35 \mathrm{~cm}$ (2.50 in.) gap between the bottom of the rods and the rotor hub. The centerline of the rods was $14.3 \mathrm{~cm}$ (5.63 in.) upstream of the rotor leading edge at the tip, or approximately one rotor chord length upstream. Data were recorded at three speed settings: 1400, 1800, and $2000 \mathrm{rpm}$.

Four distortion patterns were tested in the 2007 experiment, as shown in Figure 3. A 30-rod mounting ring allowed rods to be placed at circumferential locations separated by increments of $12^{\circ}$. Angular locations of rods pictured in Configuration 4 (2007) can be found in Reference 5.

Figure 4 shows the results of a parametric study used to design the 2010 experiment. For each rod count $(6,10$, and 15 rods), overall tone power levels were calculated as a function of circumferential spacing angle. The computation included only the $1 \mathrm{BPF}, 2 \mathrm{BPF}$, and $3 \mathrm{BPF}$ tones and assumed that only the first radial mode propagated. Sound power levels were computed at the generation plane, assumed to be the leading edge of the rotor. The spacing angle was varied from $1^{\circ}$ to the equally spaced angular position $\left(60^{\circ}, 36^{\circ}\right.$, and $24^{\circ}$, respectively) for each rod count. Tone noise minima were predicted to occur near the $17^{\circ}$ and $34^{\circ}$ angular spacing for all rod counts studied. These predictions were carried out for the 2000 rpm condition only.

Ten distortion patterns were tested in the 2010 experiment, as shown in Figure 5. In the 2010 experiment, both a 30-rod mounting ring and a 21-rod mounting ring were used. The 21-rod mounting ring allowed rods to be placed at circumferential locations separated by $17.1^{\circ}$ increments, a number that was determined by the predictions plotted in Figure 4. Both experiments also included a configuration without any rods installed.

Two 15-microphone arrays were used to record the farfield sound distribution from the ANCF. Farfield microphone measurements were acquired synchronously with shaft speed at a rate of 256 samples per revolution, which allow for processing up to the $128^{\text {th }}$ harmonic of the shaft frequency, or equivalently, up to the $8^{\text {th }}$ harmonic of the blade passing frequency (BPF) for this test (Ref. 6).

In-duct acoustic pressure measurements upstream and downstream of the rotor were acquired with the Rotating Rake system (Ref. 7). The Rotating Rake system is a continuously rotating radial microphone rake that is inserted into the duct, at either the inlet entrance or exhaust exit plane. The system utilizes spinning mode theory and Doppler-shift physics to separate circumferential modes and the cylindrical wave equation solution to reduce the radial modes. It provides a complete map of the acoustic duct modal magnitudes and phases present in the fan duct. For these experiments, the sampling rate for the Rotating Rake system was set to 128 samples per revolution, and the data were processed for the first two harmonics of blade passing frequency.

\subsection{Fan Tone Noise Predictions}

Sofrin and Mathews (Ref. 8) express sound power in a constant area annular duct with the following equation:

$$
W=\frac{1}{2 \rho a} \sum_{n=1}^{\infty} \sum_{m=-\infty}^{\infty} \sum_{\mu=1}^{\infty} a_{m n \mu} C_{m n \mu} C_{m n \mu}^{*} A_{m n \mu}
$$


Reference 5 describes how the Sofrin and Mathews (Ref. 8) relations could be expressed in a form convenient for representing irregularly spaced vanes without a small deviation angle assumption. The asymmetry in the problem is captured in the term:

$$
C_{m n} C_{m n}^{*}=V+2 \sum_{j>q} \cos \left(\beta_{q}-\beta_{j}\right)=V+2 \sum_{j>q} \cos \left((n B-m)\left(\Delta \theta_{q}-\Delta \theta_{j}\right)\right)
$$

Note that this term was expressed without a dependence upon radial mode order. Power in each of the circumferential and radial modes can be calculated from:

$$
a_{m n \mu}=\sqrt{1-1 / \xi^{2} m n \mu}
$$

Power in the inlet and exhaust duct can be calculated if one assumed the appropriate values for duct cross sectional area (noting that the area term in Equation (1) does not vary with circumferential, radial, or harmonic index, but rather varies with axial location in the duct).

What is computed here and validated against measurements is power levels for inlet and exhaust given by:

$$
\begin{gathered}
W_{\text {inlet }}=\frac{1}{2 \rho a} \sum_{n=1}^{\infty} \sum_{m=-\infty}^{\infty} \sum_{\mu=1}^{\infty} a_{m n \mu, \text { inlet }} C_{m n} C_{m n}^{*} A_{\text {inlet }} \\
W_{\text {exhaust }}=\frac{1}{2 \rho a} \sum_{n=1}^{\infty} \sum_{m=-\infty}^{\infty} \sum_{\mu=1}^{\infty} a_{m n \mu \text {,exhaust }} C_{m n} C_{m n}^{*} A_{\text {exhaust }} \\
P W L=10 * \log \left(W / W_{r e f}\right)
\end{gathered}
$$

\subsection{Comparison of Measurements and Predictions}

\subsection{Determination of Low Noise Inlet Distortion Patterns}

Figures 6 through 8 summarize the results of the 2010 inlet distortion test and compare measurements to three sets of predictions all based on the theory of Sofrin, Mathews and Koch. Figure 6 compares the measured and predicted results for the 6-rod configurations; Figure 7 compares results for the 10-rod configurations; and Figure 8 shows the 15-rod configuration results.

Only the $1 \mathrm{BPF}$ and $2 \mathrm{BPF}$ tones were included in the calculation of the overall tone power levels in Figures 6 through 8. All results shown are for the $2000 \mathrm{rpm}$ fan speed. To obtain the overall tone sound power level from the farfield microphone measurements, the data from the inlet and exhaust arrays were combined. Likewise, to obtain the overall tone sound power level from the Rotating Rake measurements, the data from the inlet and exhaust duct rakes were combined.

In general, overall tone sound power levels measured by the Rotating Rake were greater than those measured by the farfield microphone arrays. Better agreement between the Rotating Rake and farfield microphone arrays might be achievable with additional farfield microphones. The existing array does not detect variations in sound power levels in the circumferential direction. This may be of particular concern for those studying noise produced by asymmetric inflow distortions. Directivity plots from the 2007 inlet distortion test are presented in Reference 5.

Three predictions are shown in Figures 6 through 8. The prediction labeled SMK 3 shown in black assumed only the first radial mode propagated. Sound power levels in the inlet and exhaust duct were assumed to be equal to the value calculated at the generation plane (the rotor leading edge), and the 
overall sound power level was computed from their sum. These same assumptions were used to generate the predictions used to design the experiment.

The prediction labeled SMK 2 shown in cyan in Figures 6 through 8, included the estimates for all propagating radial modes. SMK 2 predictions once again assumed that sound power levels in the inlet and exhaust duct were both equal to the value calculated at the generation plane.

The prediction labeled SMK 1 shown in green in Figures 6 through 8 included estimates for all propagating radial modes. SMK 1 predictions calculated the inlet duct sound power levels at the inlet plane where the Rotating Rake is installed. SMK 1 estimates for the exhaust duct sound power levels were calculated at the exhaust plane where the exhaust Rotating Rake measurements were acquired. The overall tone sound power levels were computed from the sum of the inlet and exhaust duct estimates. These three sets of predictions are summarized in Table 1.

The trends for all configurations tested were most accurately captured by the SMK 3 predictions. Deficiencies in the predictions of all propagating radial mode sound power levels in the inlet and exhaust duct are discussed in detail below. Even so, the comparisons in Figures 6 through 8 indicate that evaluating overall tone sound power level at the generation plane may be useful in parametric studies of fan inflow distortion tone noise.

\subsection{Validation of Radial Mode Sound Power Level Predictions}

Figures 9 through 14 compare predicted circumferential and radial sound power levels to measurements from the 2007 experiment in an effort to be consistent with previous reports (Refs. 5 and 3 ). Results are shown for Configuration 1 (6 rods equally spaced) and Configuration 4 ( 8 rods, integer multiples of $12^{\circ}$ apart). The red bars represent the total sound power levels in each circumferential mode, while the other colored bars indicate the sound power levels of the radial modes. Symbols here represent calculated values. Figures 9 and 10 demonstrate that the theory generally underpredicted the circumferential and radial mode power levels for the first harmonic of the blade passing frequency tone. Including estimates for all propagating radial modes slightly improved the accuracy of the total $1 \mathrm{BPF}$ circumferential mode sound power level prediction for Configuration 4 where the second radial mode is a significant contributor.

Figures 11 and 12 compare predictions to the measurements for the same configurations for the 2 BPF harmonic. Figures 11 and 12 demonstrate that the theory generally did not accurately capture trends in measured radial mode sound power levels. While Figure 11 indicates that for Configuration 1 (6 rods equally spaced), the first radial mode power level was measured to be significantly greater than the other propagating radial modes Figure 12 indicates that this trend is not always observed when the inflow is distorted asymmetrically - for Configuration 4 ( 8 rods, integer multiples of $12^{\circ}$ apart) both the first and third radial modes are significant contributors. While including estimates for all the radial modes did generally improve the accuracy of the total circumferential mode sound power level predictions in the exhaust duct for the 2 BPF tone, this was not true for the inlet duct. In the inlet duct, radial mode sound power level predictions were generally greater than the measured values.

Significant contributions from higher order radial modes were most evident for the more asymmetric cases studied at design speed of $2000 \mathrm{rpm}$ (Configurations 3 and 4, 2007). The first radial mode became more dominant for all cases studied as speed was decreased, as shown in Figures 10 and 11, showing the $2 \mathrm{BPF}$ results for Configuration 1 and 4 at $1800 \mathrm{rpm}$. These experiments demonstrate that asymmetry in the inlet distortion pattern can change both the circumferential and radial mode sound power level distributions.

\subsection{Validation of Inlet and Exhaust Duct Sound Power Level Predictions}

Figures 15 and 16 compare predicted sound power levels to measurements from the 2007 experiment. Both figures compare the total sound power level in each circumferential mode to the contributions from the inlet and exhaust duct individually. The colored bars represent the rotating rake measurements, while 
the symbols indicate the predictions. Results are again shown for Configuration 1 ( 6 rods equally spaced) and Configuration 4 ( 8 rods, integer multiples of $12^{\circ}$ apart) from the 2007 experiment at $2000 \mathrm{rpm}$.

It was discovered that for positive circumferential modes $(m>0)$, measured circumferential mode sound power levels in the exhaust duct were greater than those in the inlet duct $\left(P W L_{m, e x}>P W L_{m, i n}\right)$, and vice versa - for negative circumferential modes $(m<0)$, measured total circumferential mode sound power levels in the exhaust duct were less than those in the inlet duct $\left(P W L_{m, e x}<P W L_{m \text {, in }}\right)$. These trends were present in both the 2010 and 2007 data sets, most evident in the 1 BPF results though they are also seen in many of the 2 BPF results. None of the predictions captured these trends.

The overall sound power levels for all four configurations tested in 2007 are shown in Figure 17. The overall sound power levels shown in Figure 17 only included contributions from the first two BPF harmonics. Again differences between measured trends may be attributed to limitations in the farfield data set. While the farfield microphone array did capture the directivity of sound power level at a fixed circumferential position, the array did not capture any directivity in the circumferential direction. The farfield microphone array is illustrated in Figure 1, and angular positions of the microphones have been tabulated in Reference 5.

Two sets of predictions are shown in Figure 17. SMK Prediction 1 included all propagating radial modes. Sound power levels at the inlet plane and the exhaust plane were calculated and combined to find the overall sound power levels for the 1 BPF and 2 BPF tones. SMK Prediction 3 included the first radial mode only. Sound power levels in the inlet and exhaust duct were assumed to be equal to the value calculated at the generation plane (rotor leading edge). The reader may again refer to Table 1 for a summary of the assumptions associated with the predictions. Measured trends are more similar to SMK Prediction 3, again indicating that calculating overall sound power levels at the generation plane may be useful in studying fan tone noise produced by asymmetric inflow distortions.

Finally, if one does not limit the overall sound power level calculation to the first two harmonics of blade passing frequency, but rather include contributions from the first seven harmonics, shortcomings in the theory become very evident. Figure 18 compares the overall sound power levels for each harmonic measured by the farfield microphone array and from predictions for Configuration 4 of the 2007 test. Clearly, the theory does not accurately represent the amplitude of the higher order radial mode sound power levels and improvements in this area are needed.

\subsection{Conclusion}

Fan inflow distortion tone noise has been studied computationally and experimentally at NASA Glenn Research Center. Data from two experiments in the NASA Glenn Advanced Noise Control Fan rig have been used to validate acoustic predictions. It was found that trends in overall sound power level computed using the theory of Sofrin, Mathews, and Koch agreed well with measured trends if sound power levels in the inlet and exhaust duct were assumed to be equal to the value calculated at the generation plane (the rotor leading edge) and limited to include the first two harmonics. Predicted trends in the overall sound power level were proven to be useful in indentifying circumferentially asymmetric distortion patterns that would reduce overall inlet distortion tone noise, as compared to symmetric arrangements of rods.

While the theory could also be used to calculate the tone sound power levels at the inlet and exhaust planes, measured trends in sound power levels were not accurately predicted. Likewise, while the theory can be applied to estimate sound power levels for all propagating radial modes, predicted trends did not agree well with measurements. Deficiencies in the model can clearly be seen for this fan for higher blade passing frequency harmonics that typically have many propagating modes.

Finally, examination of the data from both experiments uncovered a trend in the data--for positive circumferential modes, measured circumferential mode sound power levels in the exhaust duct were greater than those in the inlet duct, and for negative circumferential mode, measured total circumferential mode sound power levels in the exhaust duct were less than those in the inlet duct. 
These investigations are useful in further defining the physics of fan inflow distortion tone noise. Insight will be used to guide the design of future experiments and the development of new tone noise prediction codes.

\section{References}

1. Hall, C. A. and Crichton, D., "Engine and Installation Configurations for a Silent Aircraft," ISABE2005-1164, 2005.

2. Goodman, J. R., "Noise Control in Space Shuttle Orbiter," nc10_218, 2010.

3. Koch, L. D., "Predicted and Measured Modal Sound Power Levels for a Fan Ingesting Distorted Inflow," AIAA 2010-3715, 2010.

4. Meyer, H. D. and Envia, E., "Aeroacoustic Analysis of Turbofan Noise Generation," NASA CR$4715,1996$.

5. Koch, L. D., “An Experimental Study of Fan Inflow Distortion Tone Noise,” NASA/TM-2010215844, 2010.

6. Loew, R. A., Lauer, J. T., McAllister, J. and Sutliff, D. L., "The Advanced Noise Control Fan," NASA/TM-2006-214368, 2006.

7. Sutliff, D. L., "Rotating Rake Turbofan Duct Mode Measurement System," NASA/TM-2005213828, 2005.

8. Sofrin, T. G. and Mathews, D. C., "Asymmetric Stator Interaction Noise," Journal of Aircraft, Vol. 17, Issue 8, 1979, 554-560.

TABLE 1.-DESCRIPTION OF PREDICTION ASSUMPTIONS

\begin{tabular}{|l|l|}
\hline \multicolumn{1}{|c|}{ Prediction label } & \multicolumn{1}{c|}{ Prediction assumptions } \\
\hline SMK 1 & all propagating radial modes predicted at inlet and exhaust plane locations \\
\hline SMK 2 & $\begin{array}{l}\text { all propagating radial modes predicted at generation plane (rotor leading edge); } \\
\text { inlet and exhaust duct sound power levels assumed to be equal }\end{array}$ \\
\hline SMK 3 & $\begin{array}{l}\text { only the first radial mode predicted at the generation plane (rotor leading edge); } \\
\text { inlet and exhaust duct sound power levels assumed to be equal }\end{array}$ \\
\hline
\end{tabular}




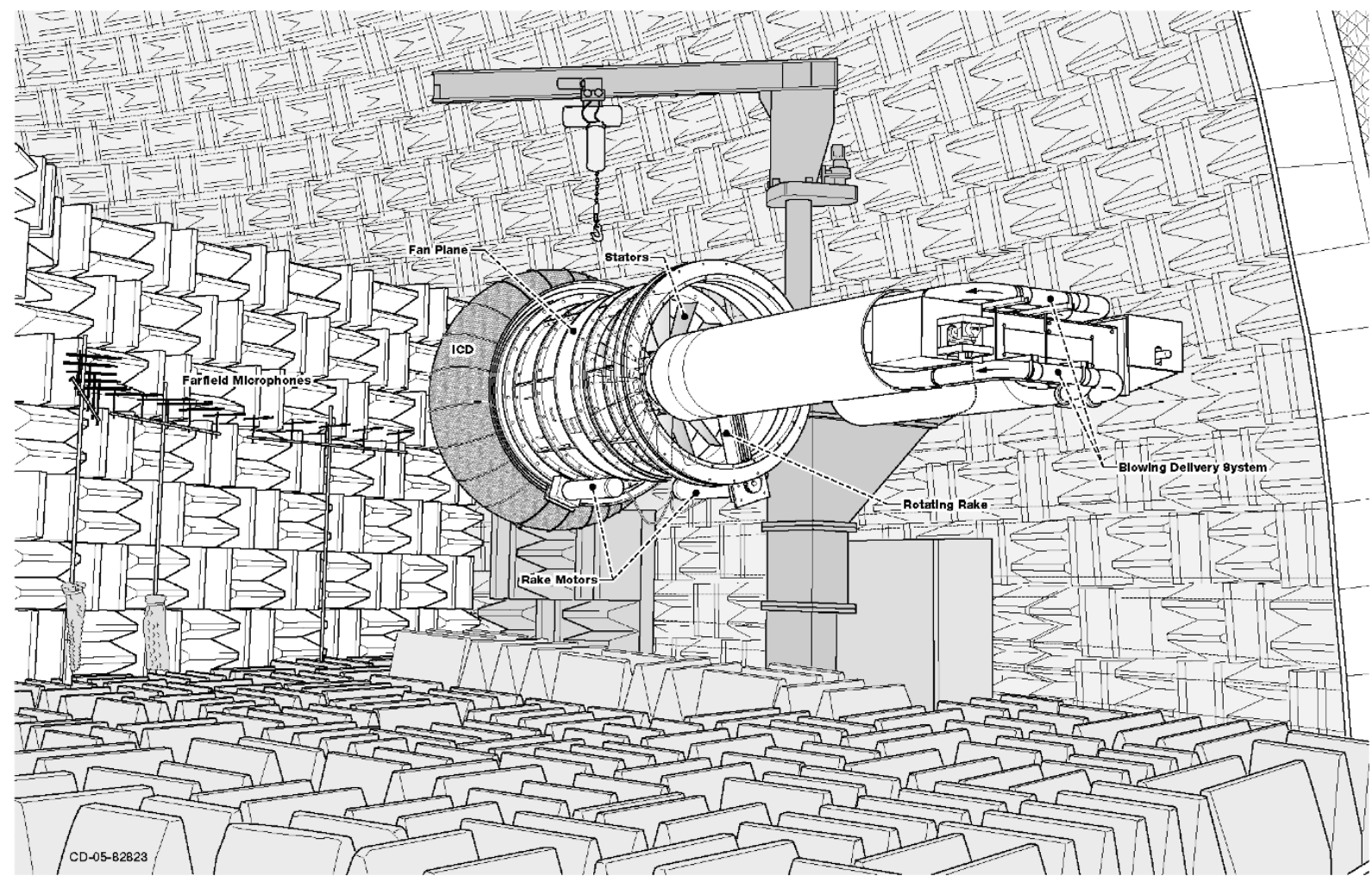

Figure 1.-The Advanced Noise Control Fan in the NASA Glenn AeroAcoustic Propulsion Lab.

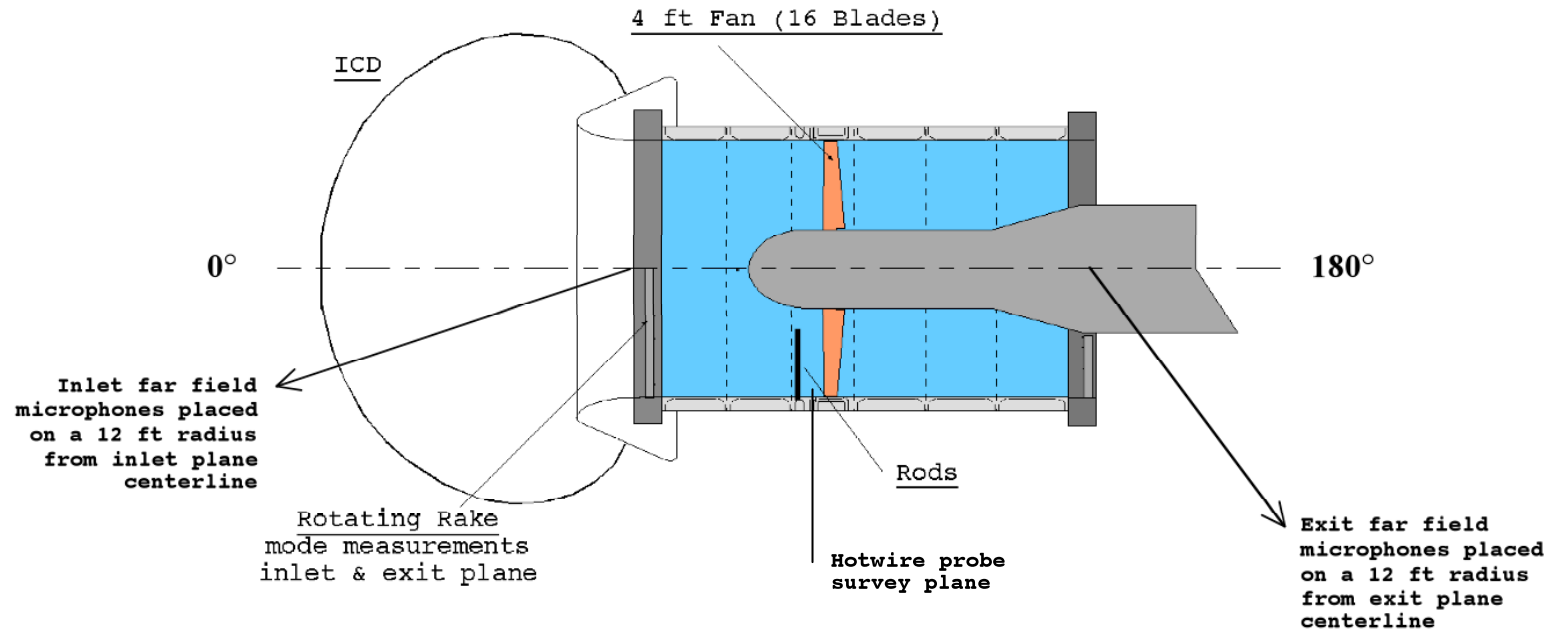

Figure 2.-Cross-sectional diagram of Advanced Noise Control Fan for the inlet distortion tests. 


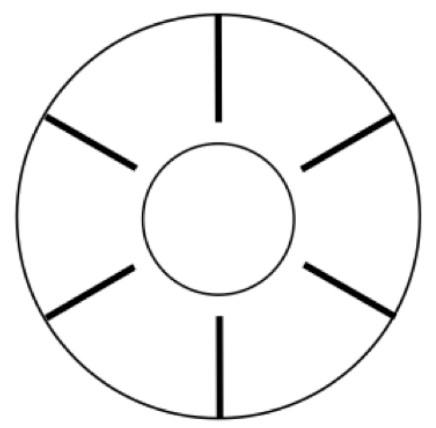

Configuration 1

6 rods $60^{\circ}$ apart

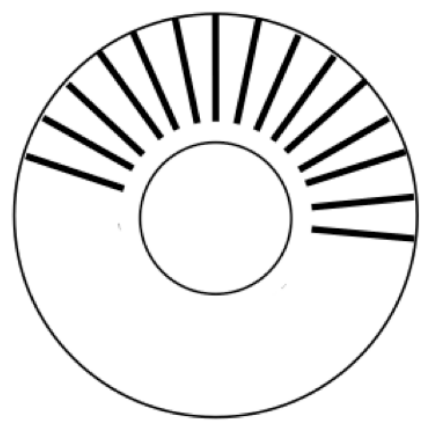

Configuration 3

15 rods $12^{\circ}$ apart

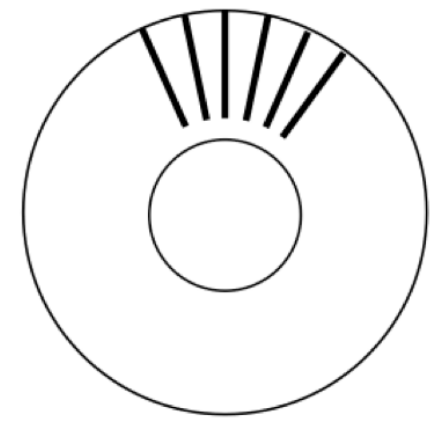

Configuration 2

6 rods $12^{\circ}$ apart

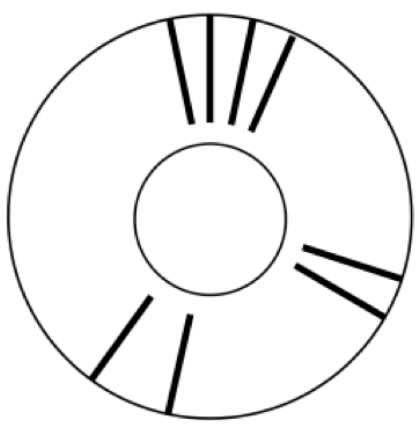

Configuration 4

8 rods integer multiples of $12^{\circ}$

Figure 3.-Circumferential locations of inlet distortion rods tested in 2007 in the ANCF at NASA Glenn.

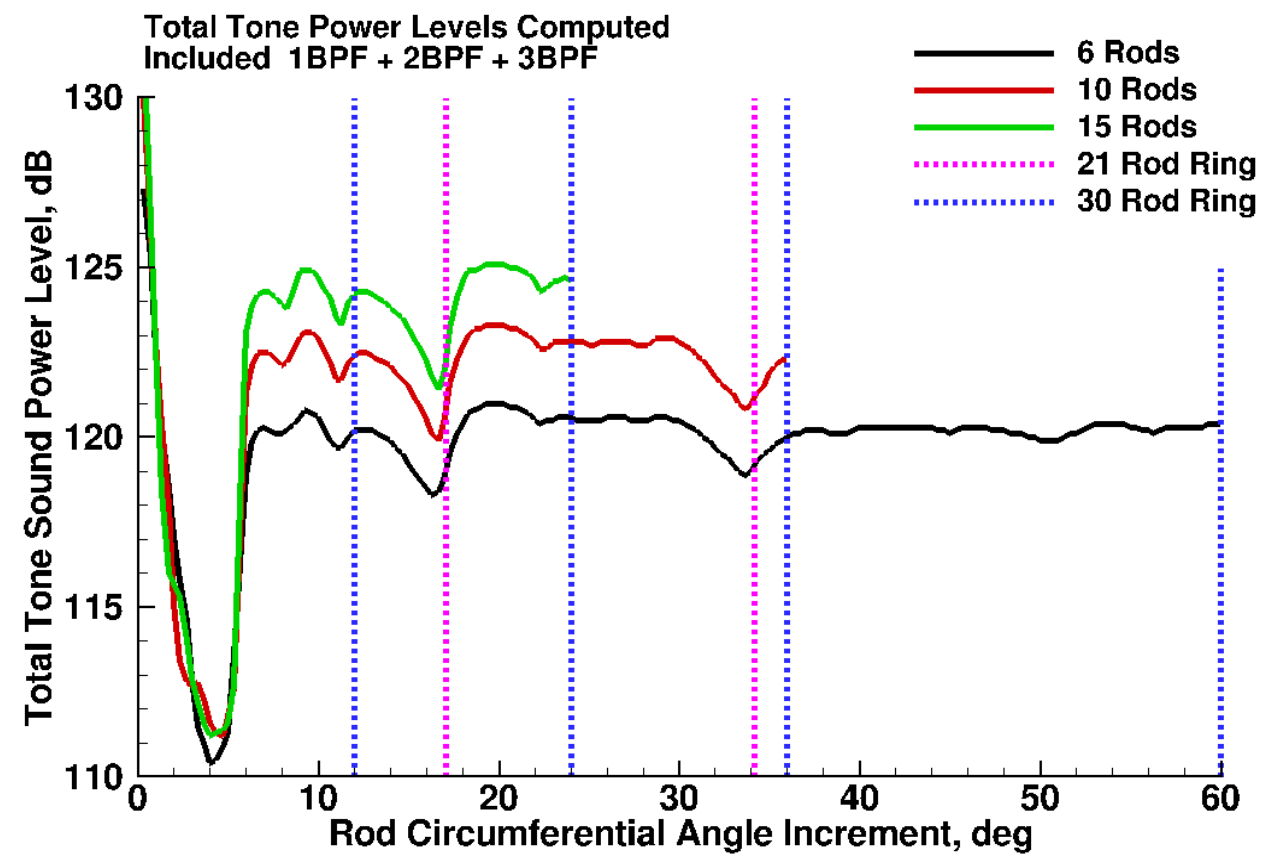

Figure 4.-Total Tone Sound Power Level predictions as a function of rod circumferential spacing angle measured in degrees used to design 2010 ANCF inlet distortion test. Vertical lines indicate angular spacing possible with the 30 -rod and 21-rod mounting rings. 


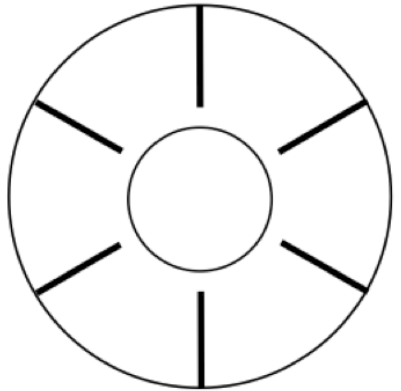

Configuration 1

6 equally spaced rods $60^{\circ}$

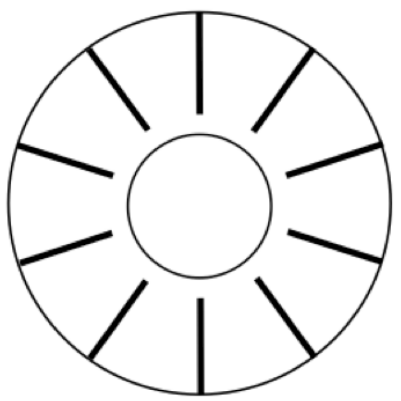

Configuration 2

10 equally spaced rods $36^{\circ}$

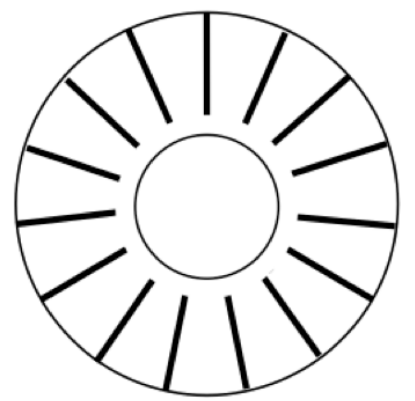

Configuration 3

15 rods equally spaced $24^{\circ}$

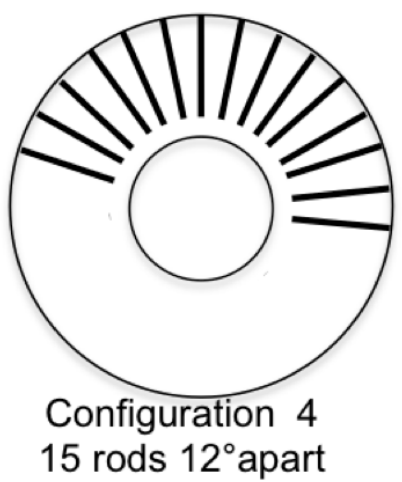

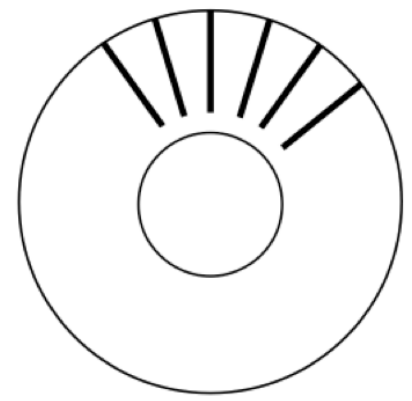

Configuration 6

6 rods $17.1^{\circ}$ apart

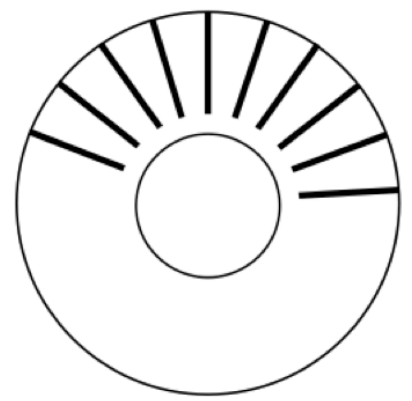

Configuration 7

10 rods

integer multiples of $17.1^{\circ}$

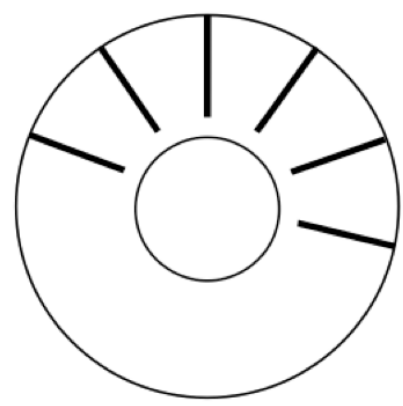

Configuration 9

6 rods $34.2^{\circ}$ apart

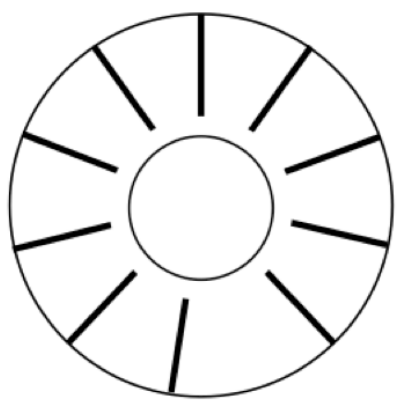

Configuration 10

10 rods

integer multiples of $34.2^{\circ}$

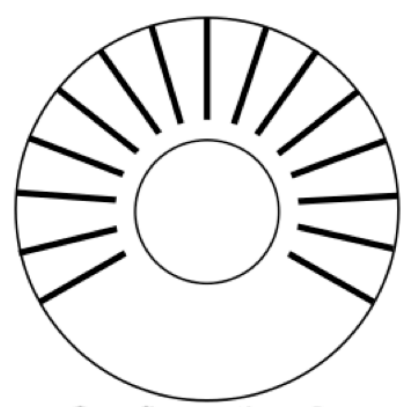

Configuration 8 15 rods

integer multiples of $17.1^{\circ}$

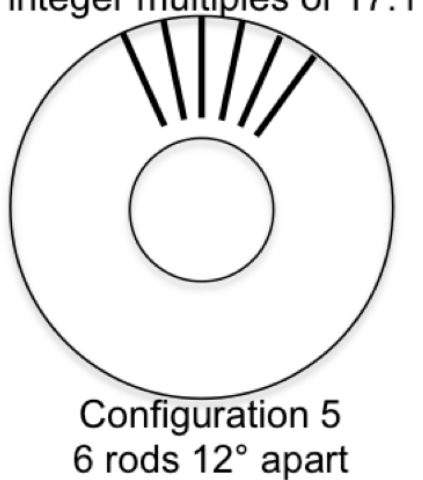

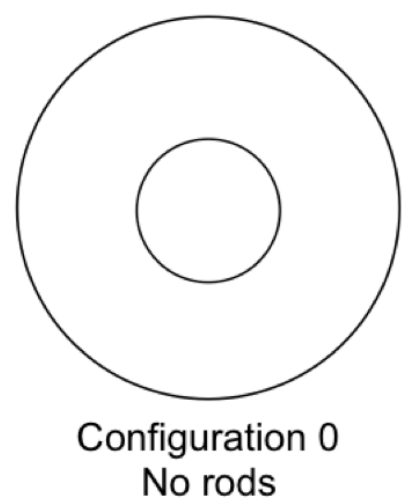

Figure 5.-Circumferential locations of inlet distortion rods tested in 2010 in the ANCF at NASA Glenn. 


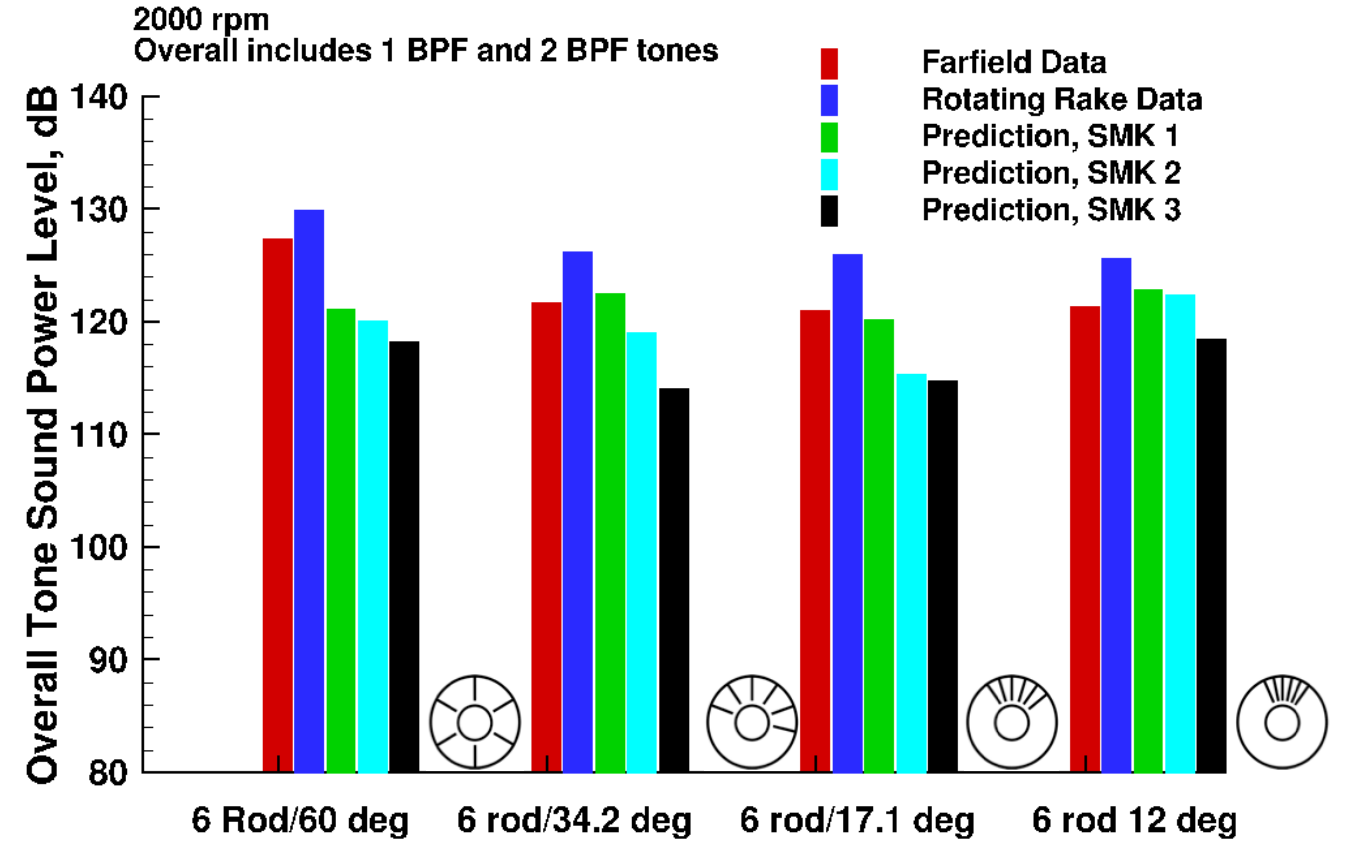

Figure 6.-Comparison of measured and predicted overall tone sound power levels for 2010 6-rod configurations at $2000 \mathrm{rpm}$. Calculation of overall sound power levels includes contributions from the first two harmonics of the blade passing frequency tone only.

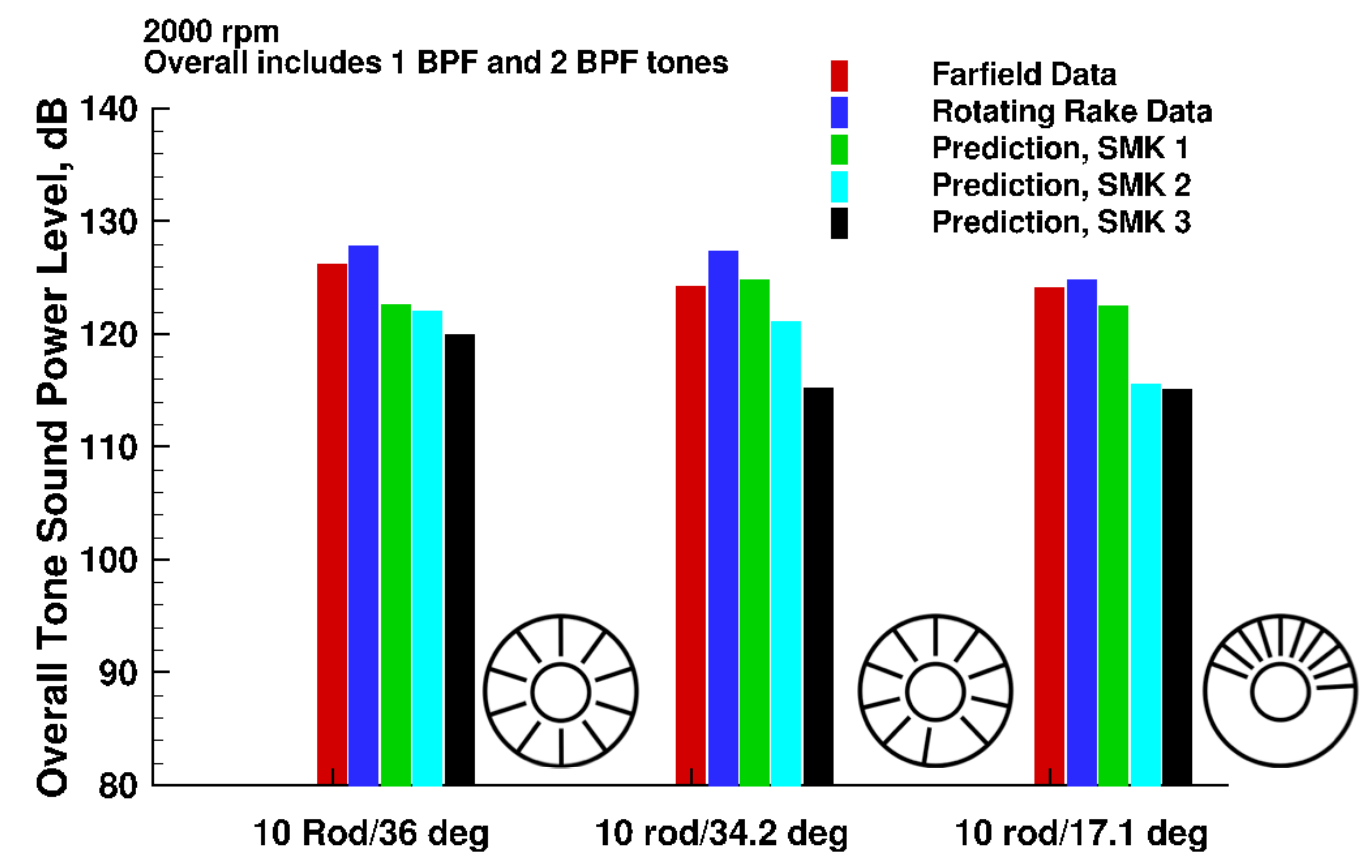

Figure 7.-Comparison of measured and predicted overall tone sound power levels for 2010 10-rod configurations at $2000 \mathrm{rpm}$. Calculation of overall sound power levels includes contributions from the first two harmonics of the blade passing frequency tone only. 


\section{$2000 \mathrm{rpm}$}

Overall includes $1 \mathrm{BPF}$ and $2 \mathrm{BPF}$ tones

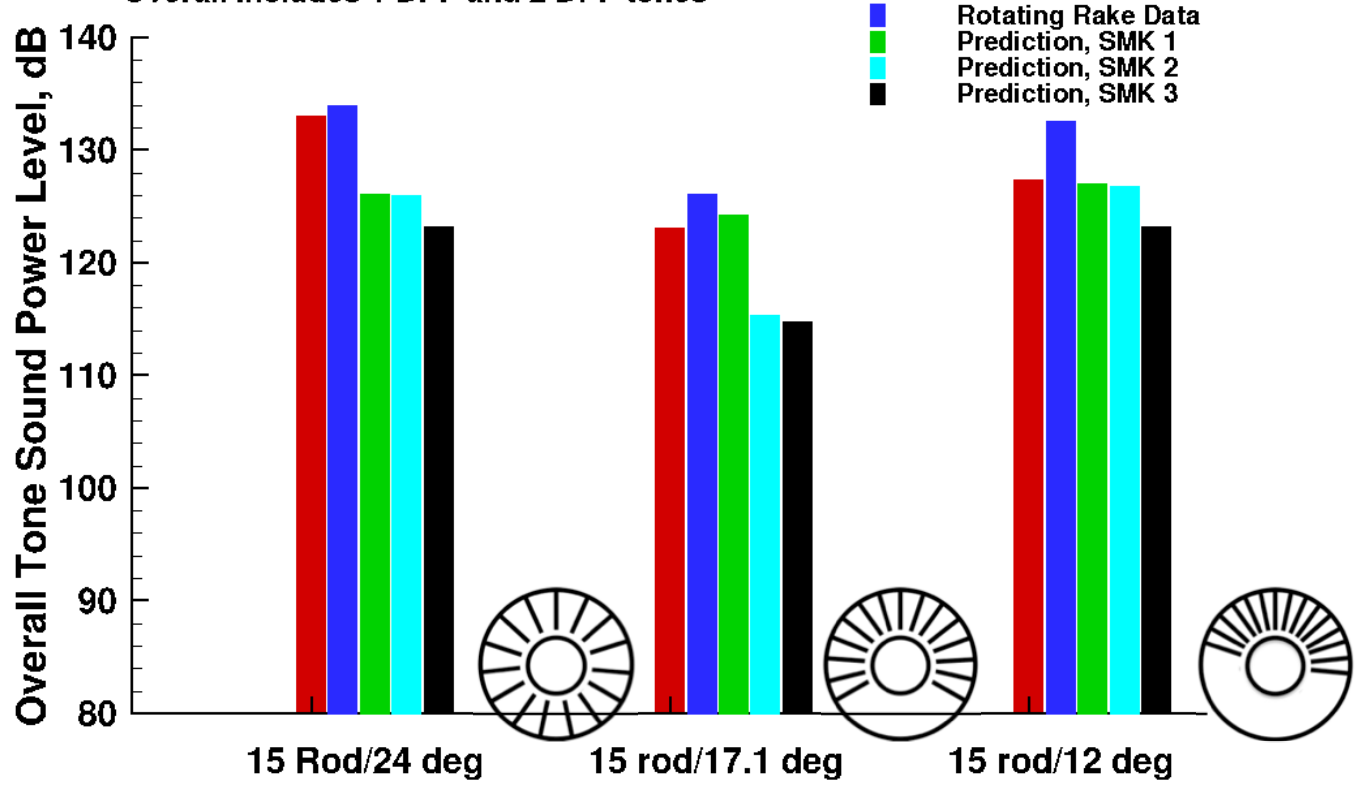

Figure 8.-Comparison of measured and predicted overall tone sound power levels for 2010 15-rod configurations at $2000 \mathrm{rpm}$. Calculation of overall sound power levels includes contributions from the first two harmonics of the blade passing frequency tone only. 
Configuration 1

6 pins, 60 degrees apart

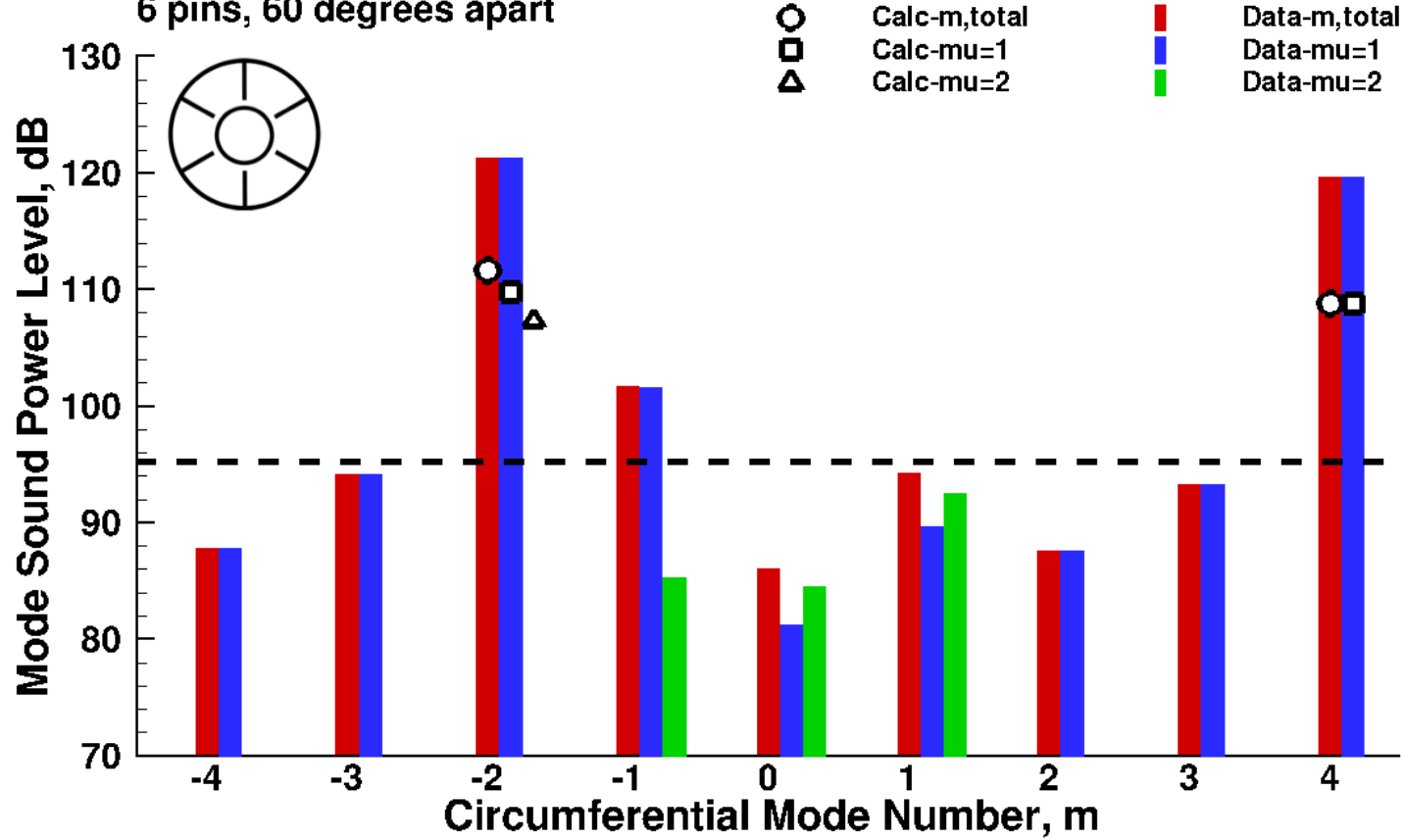

Configuration 1

6 pins, 60 degrees apart

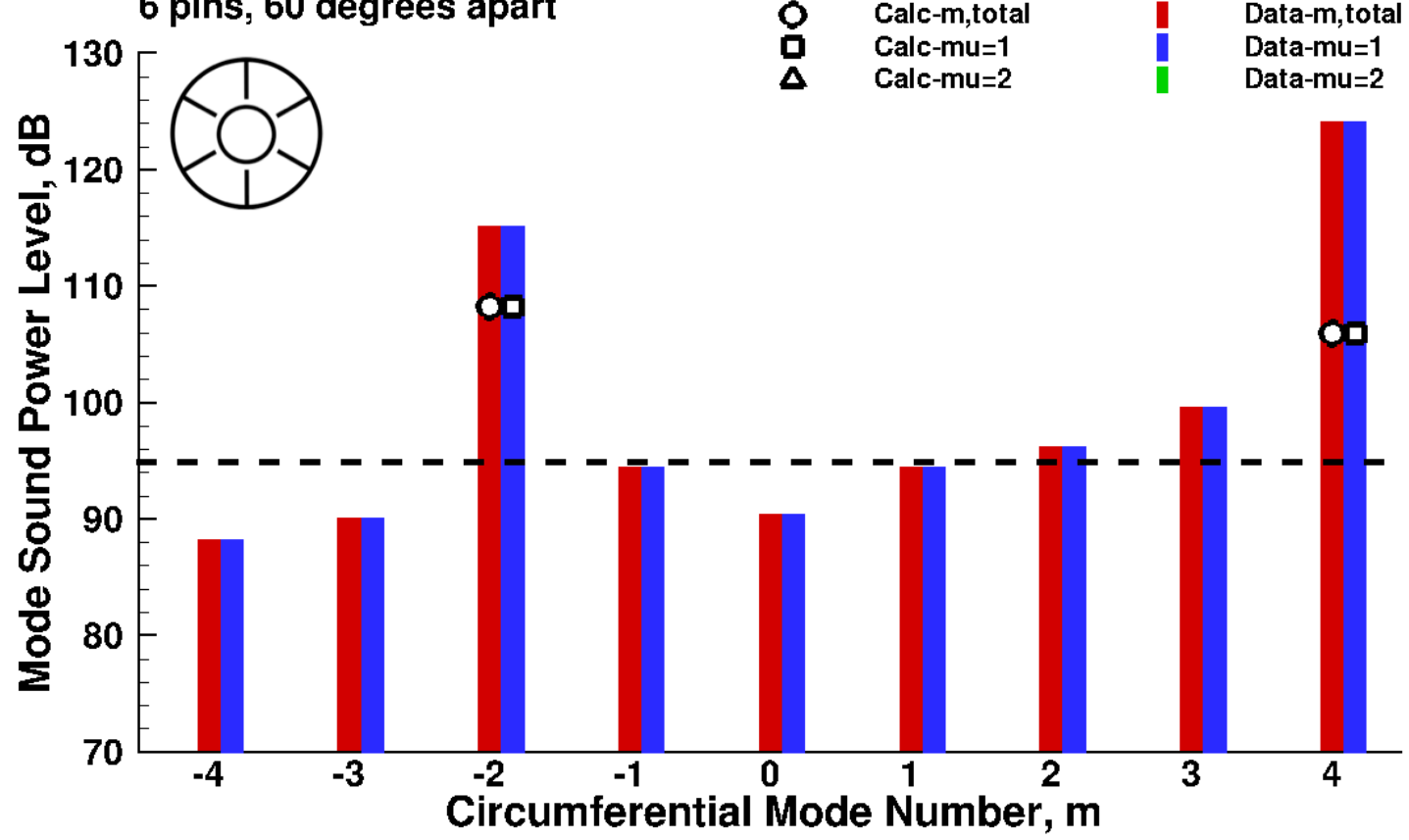

(a)

(b)

Figure 9.-Predicted and measured in-duct circumferential and radial sound power levels for Configuration 1 (2007), 1BPF, $2000 \mathrm{rpm}$. Horizontal dashed line indicates noise floor for the data set. (a) Inlet duct and (b) exhaust duct. 


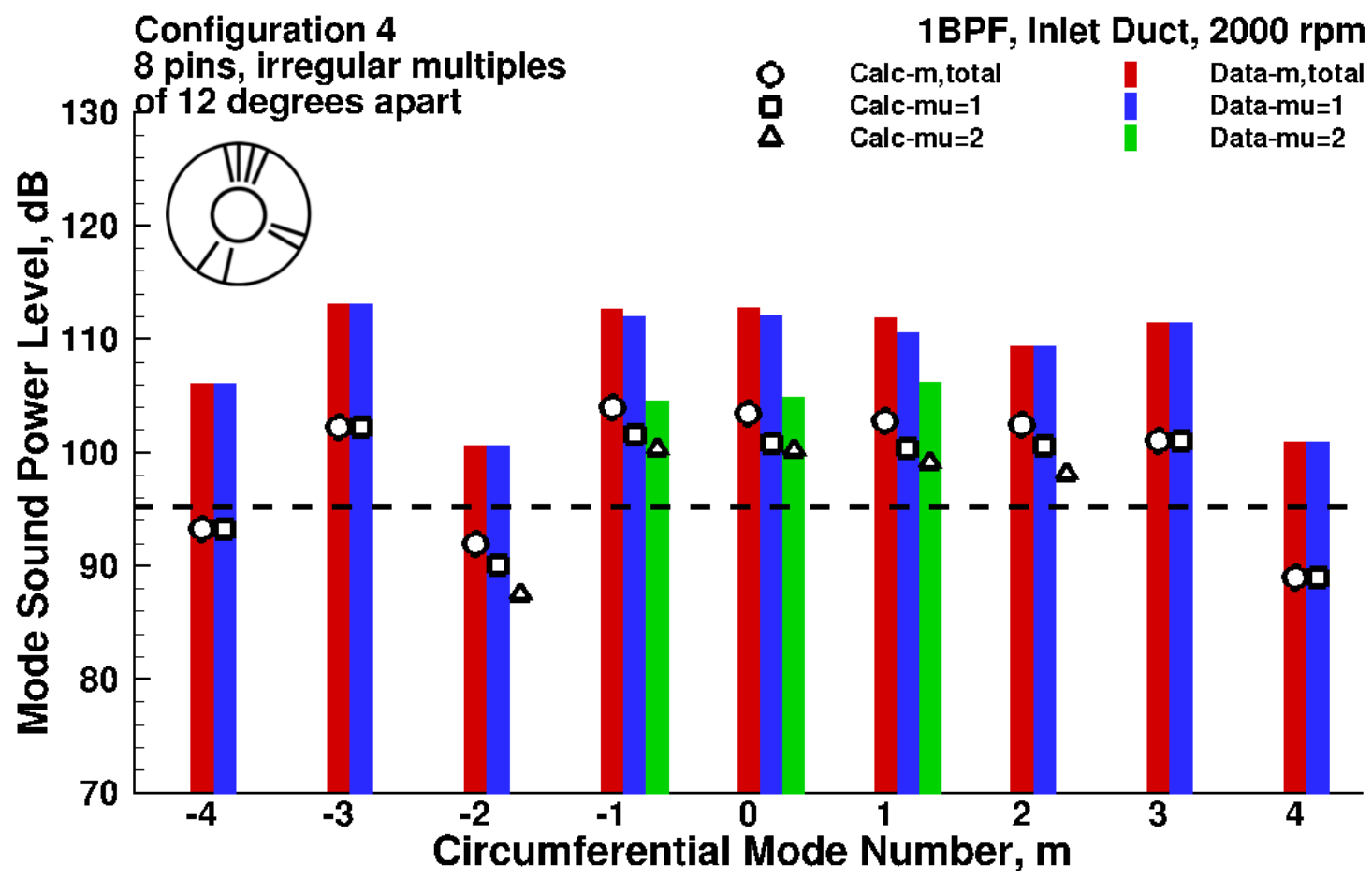

(a)

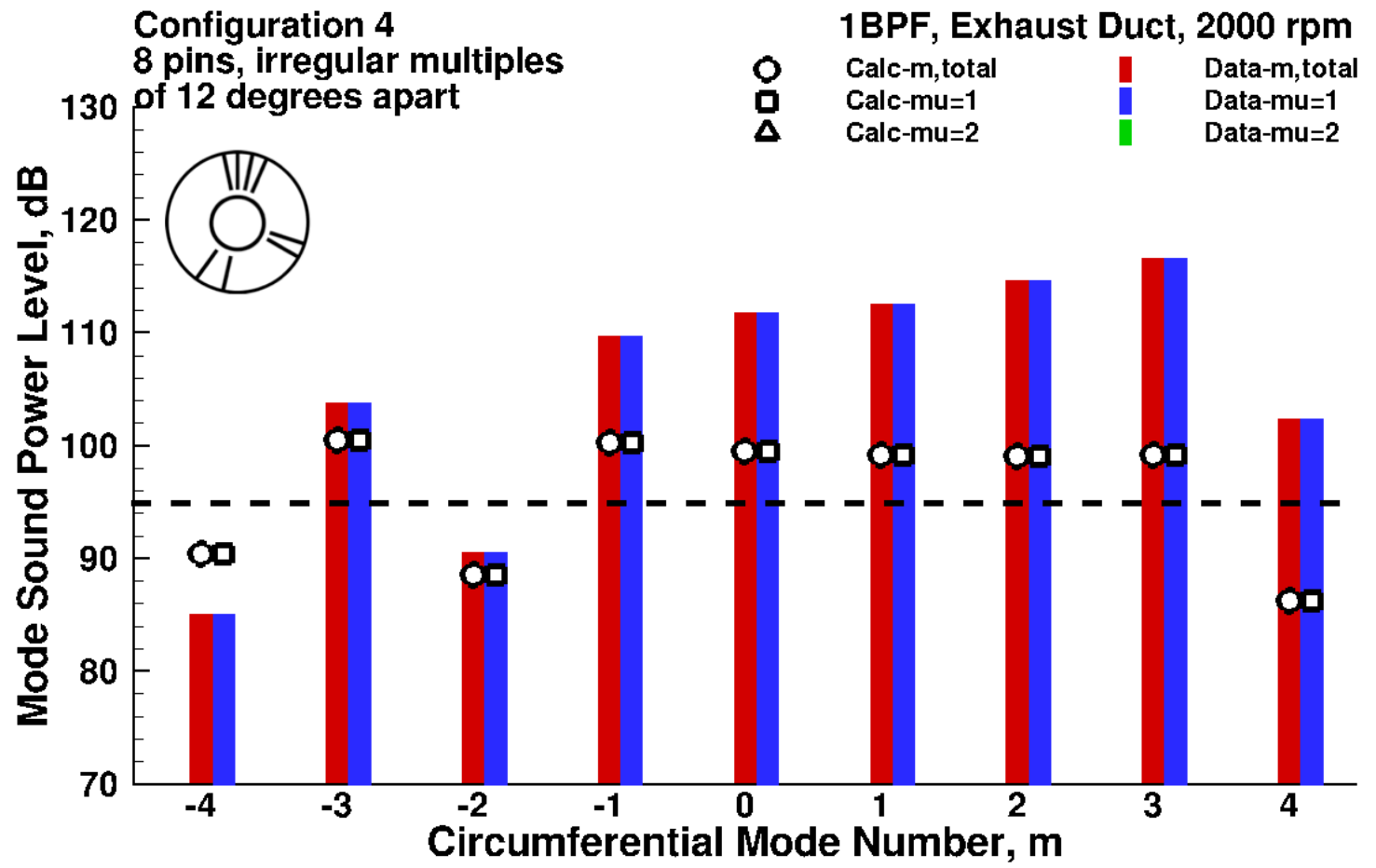

(b)

Figure 10.-Predicted and measured in-duct circumferential and radial sound power levels for Configuration 4 (2007), 1 BPF, 2000 rpm. Horizontal dashed line indicates noise floor for the data set. (a) Inlet duct and (b) exhaust duct. 


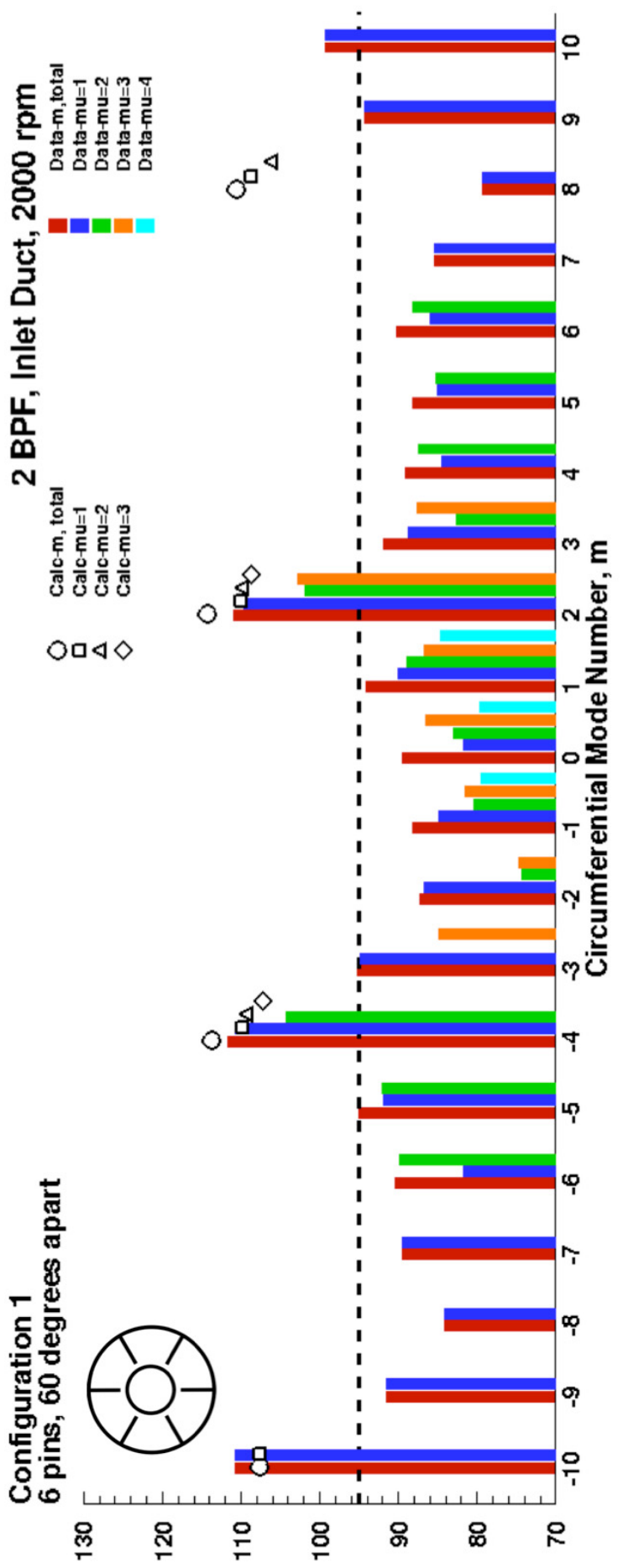

gр ‘ ґәәך גәмод punos әроW

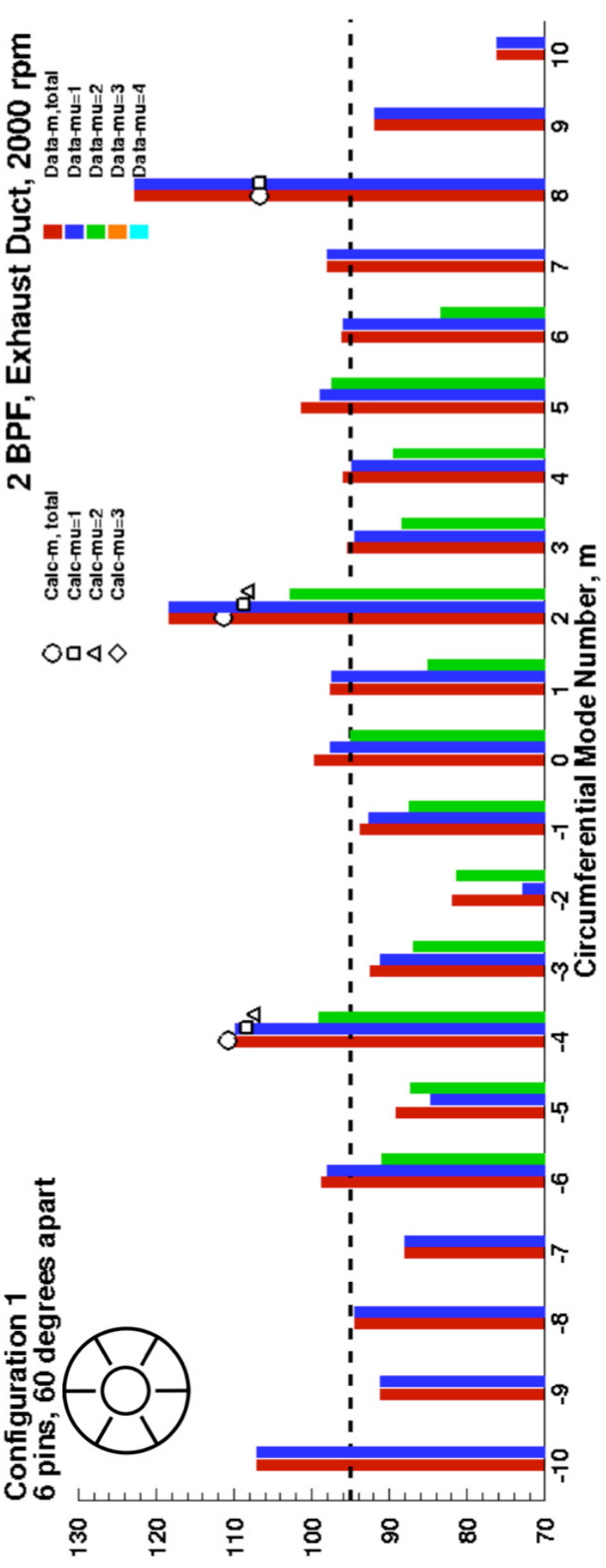

gр ‘ әәәך גәмод punos әроw

(a)

(b)

Figure 11.-Predicted and measured in-duct circumferential and radial mode sound power levels for Configuration 1 (2007), 2 BPF, 2000 rpm. Horizontal dotted line indicates the noise floor for the data set. (a) Inlet duct and (b) exhaust duct. 


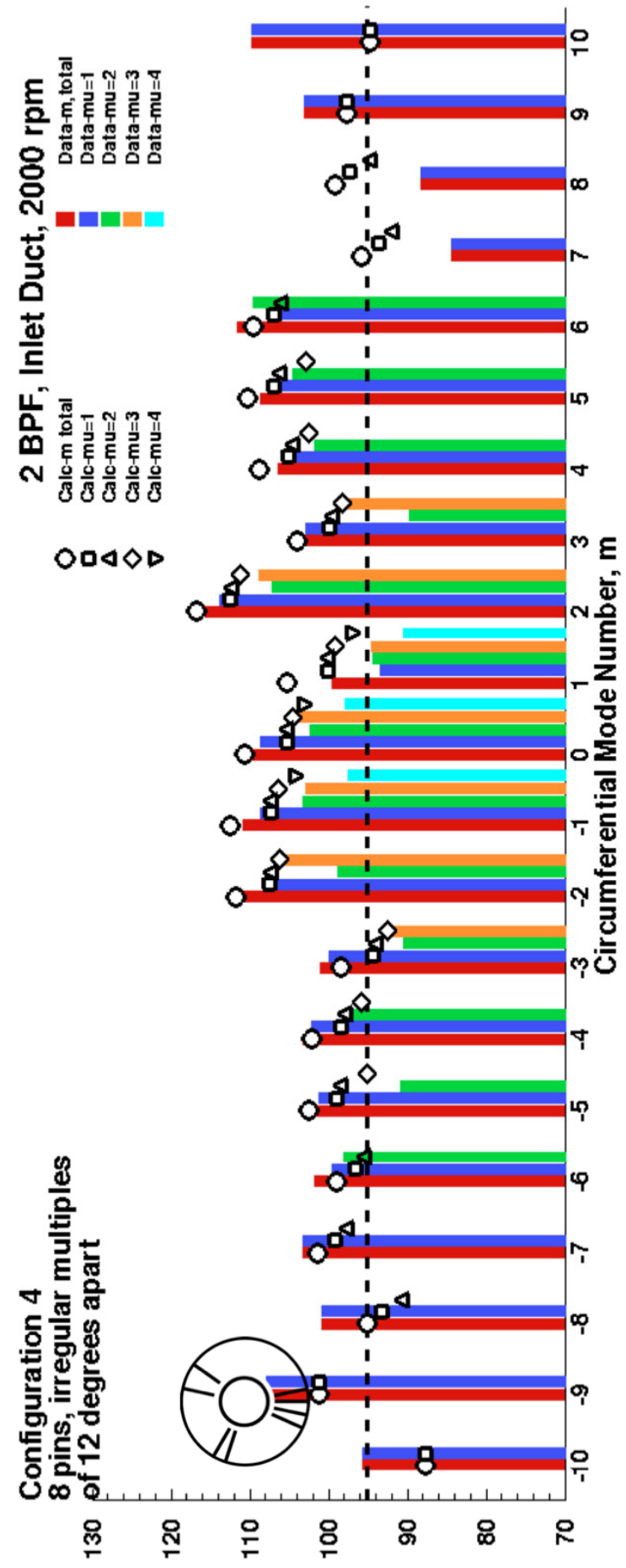

gp 'әләך גәмод punos әроW

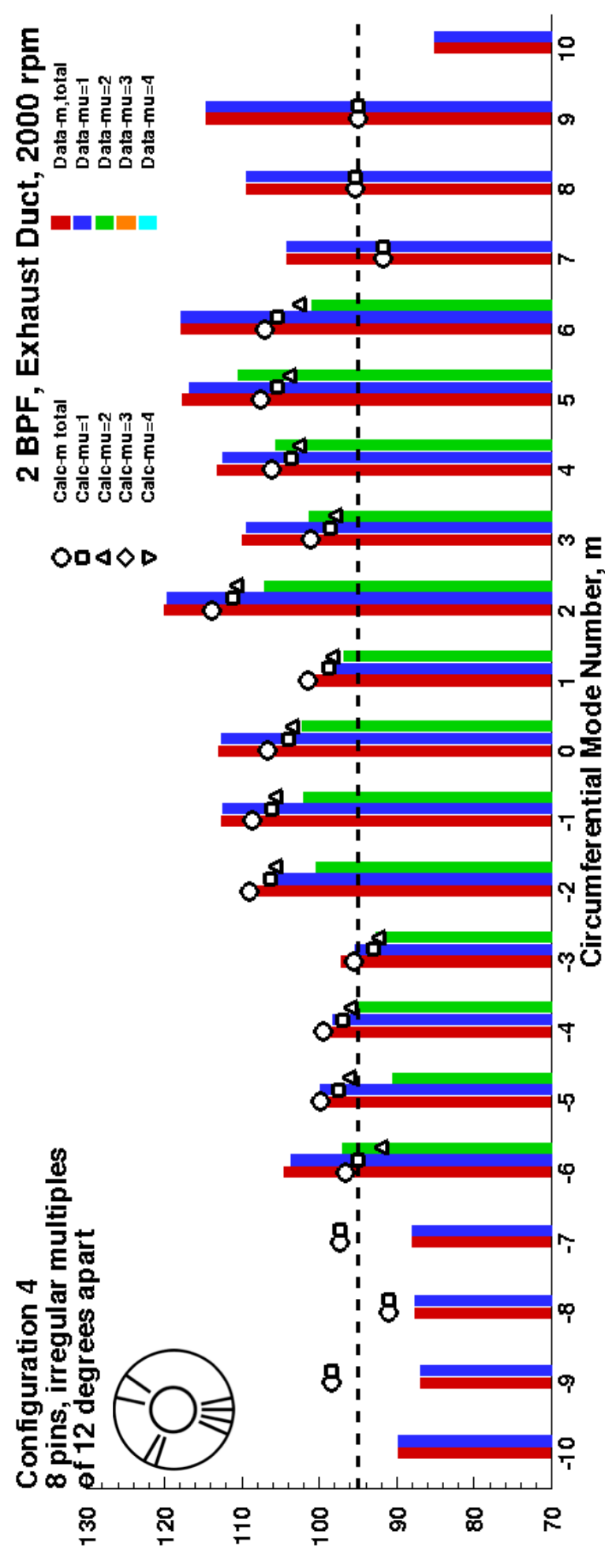

gp ‘әАәา dәмод punos әроW

(a)

(b)

Figure 12.-Predicted and measured in-duct circumferential and radial mode sound power levels for Configuration 4

(2007), 2 BPF, 2000 rpm. Horizontal dotted line indicates the noise floor for the data set. (a) Inlet duct and

(b) exhaust duct. 


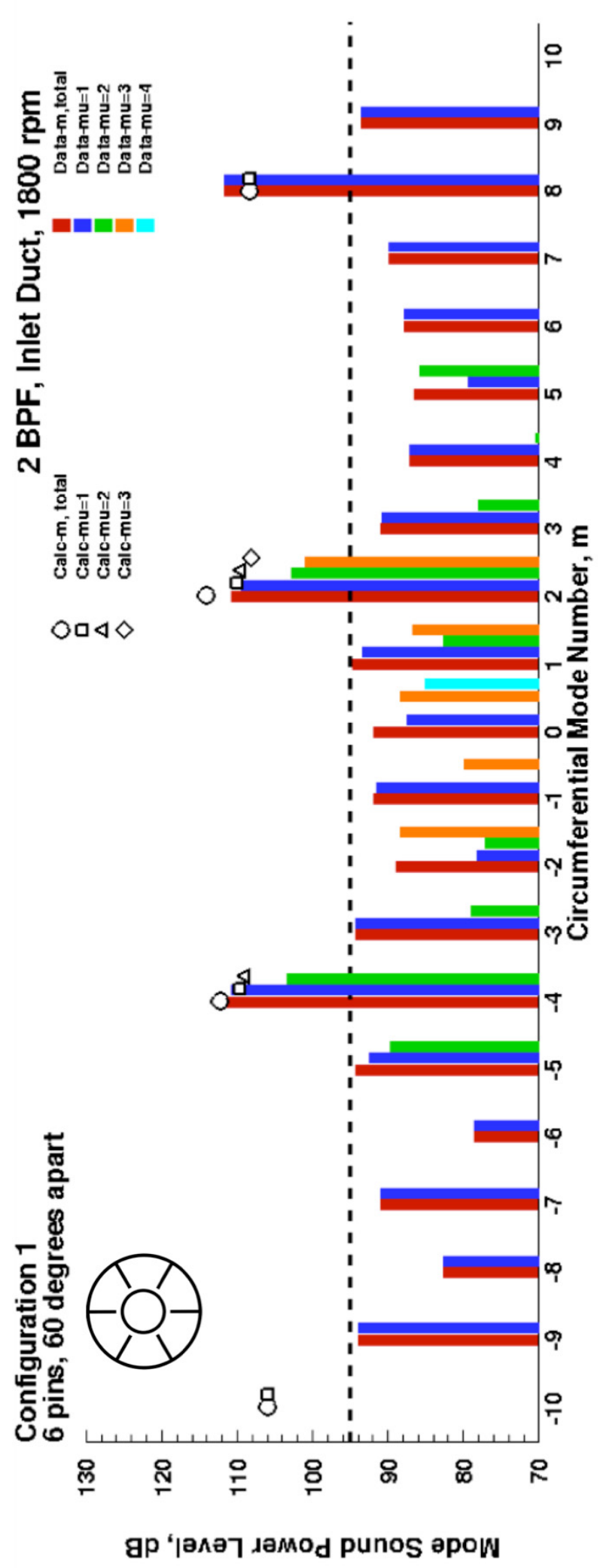

(a)

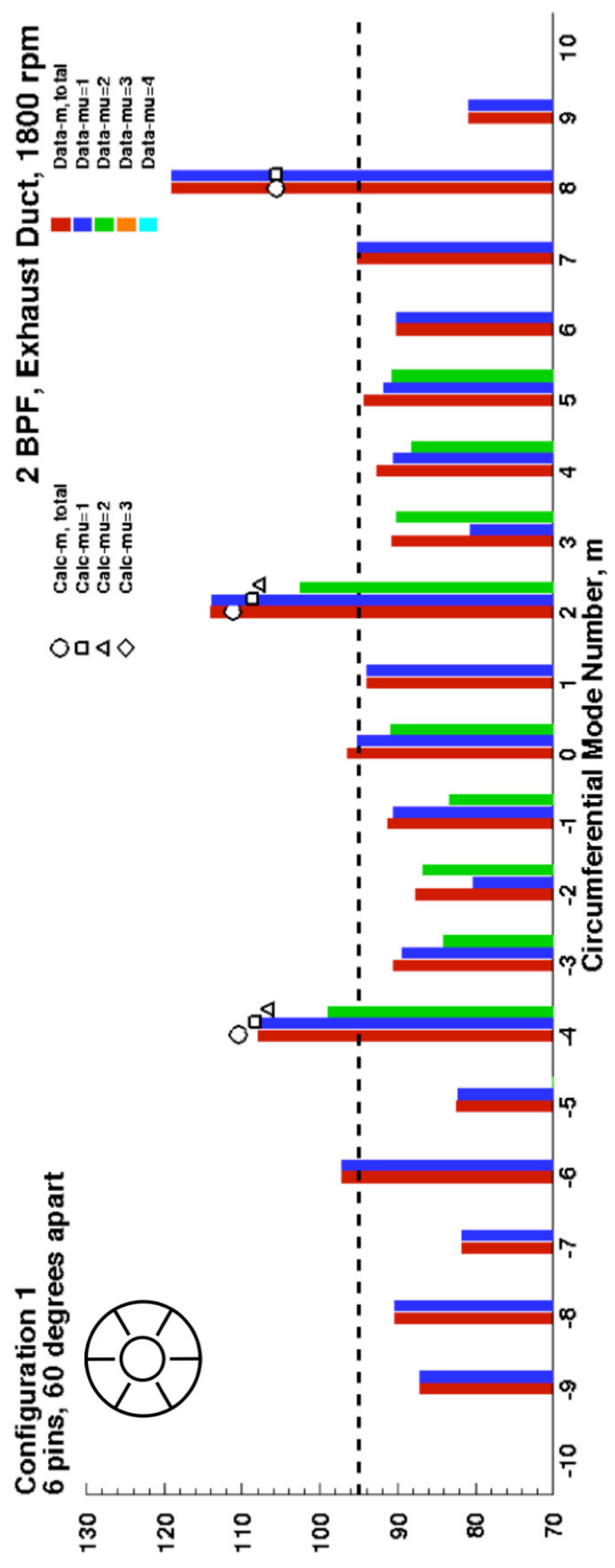

gp ‘

(b)

Figure 13.-Predicted and measured in-duct total, inlet-total, exhaust-total circumferential mode sound power levels for Configuration 1 (2007), 2 BPF, $1800 \mathrm{rpm}$. Horizontal dotted line indicates the noise floor for the data set. (a) Inlet duct and (b) exhaust duct. 


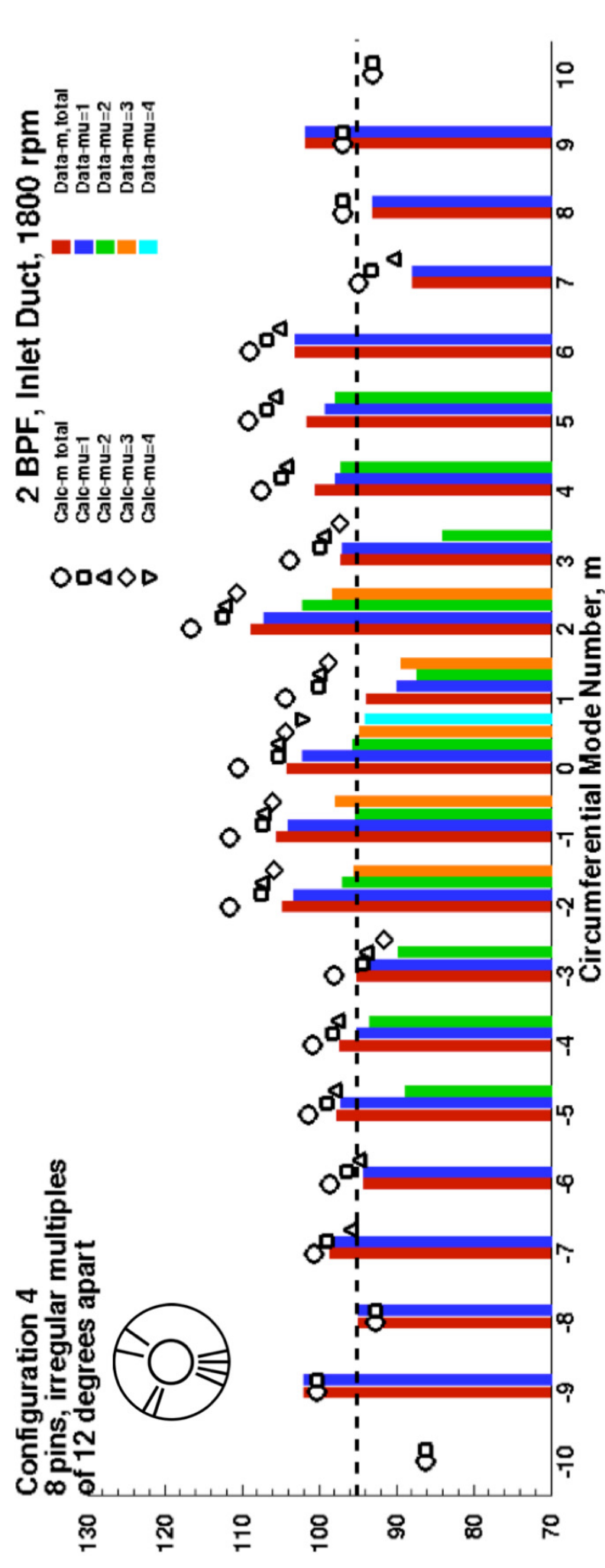

gp 'әәлаך dәMоd punos әроW
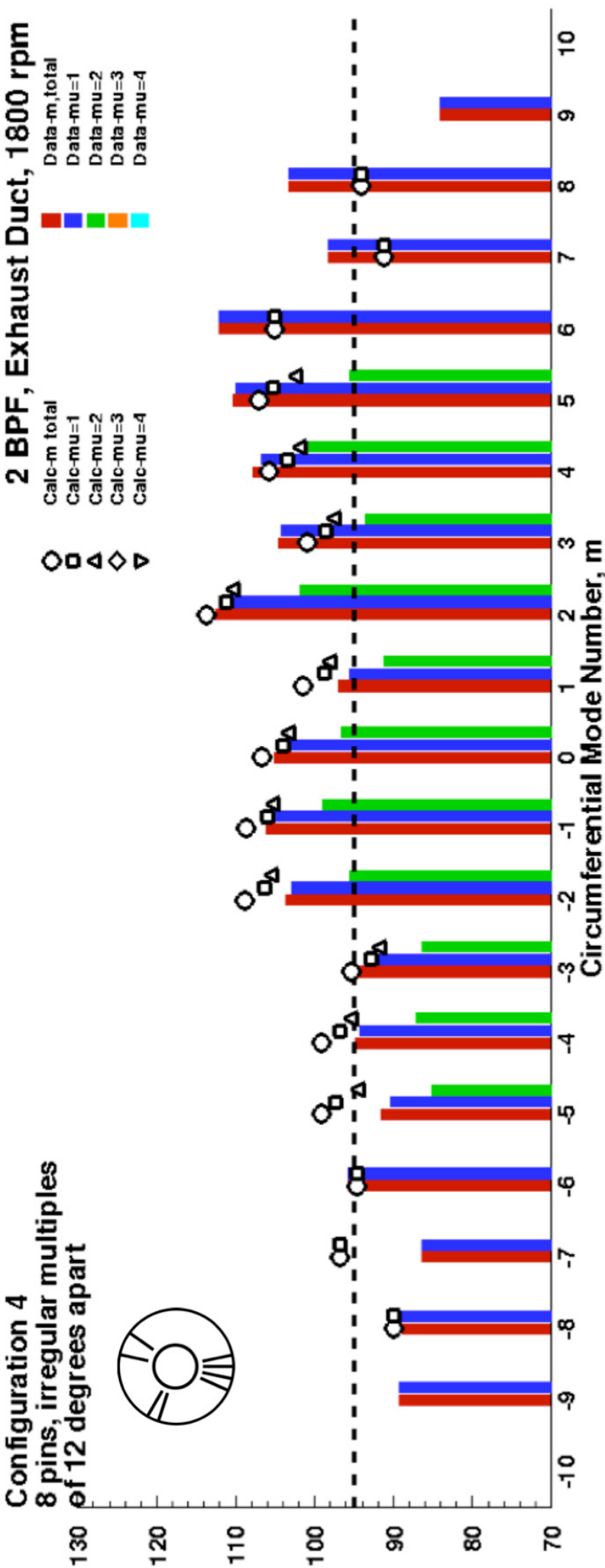

gр ‘ ґАәך дәмод punos әроw

(a)

(b)

Figure 14.-Predicted and measured in-duct circumferential and radial sound power levels for Configuration 4 (2007) 1BPF, $1800 \mathrm{rpm}$. Horizontal dashed line indicates noise floor for the data set. (a) Inlet duct and (b) exhaust duct. 


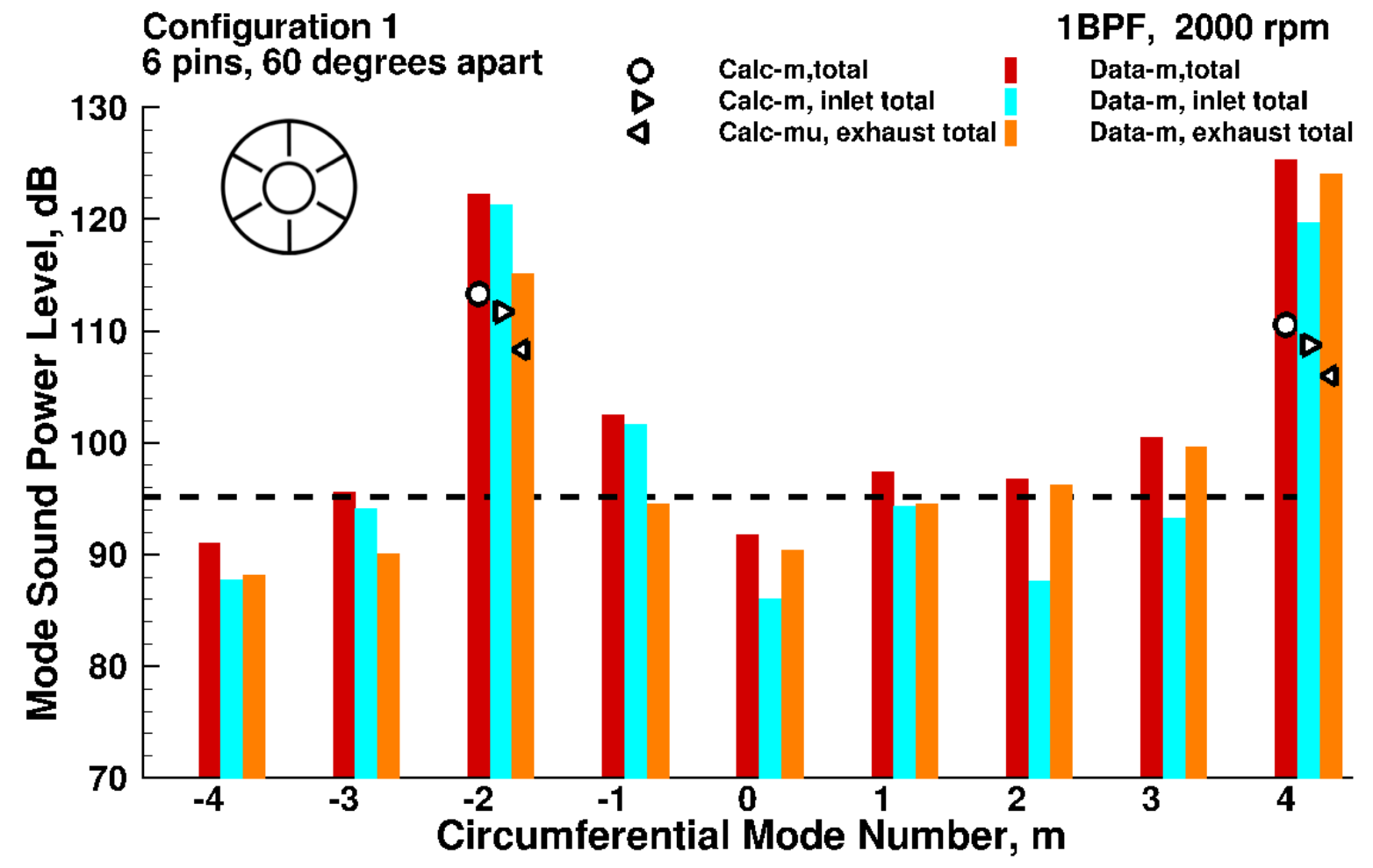

(a)

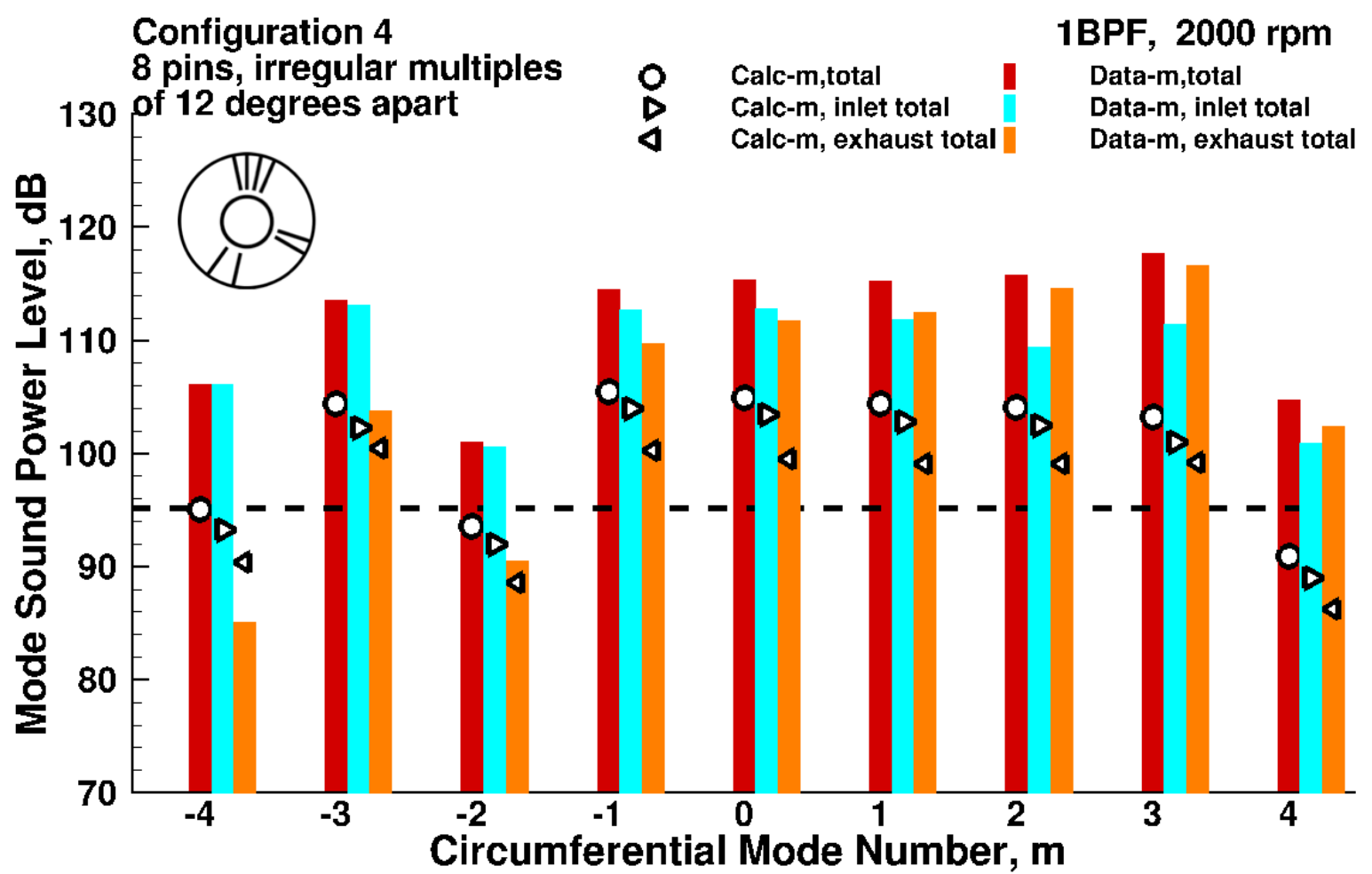

(b)

Figure 15.-Predicted and measured in-duct total, inlet-total, exhaust-total circumferential mode sound power levels for $1 \mathrm{BPF}, 2000 \mathrm{rpm}$. Horizontal dotted line indicates the noise floor for the data set. Uncertainty in measured mode sound power levels is $\pm 2 \mathrm{~dB}$. (a) Configuration 1 (2007) and (b) Configuration 2 (2007). 

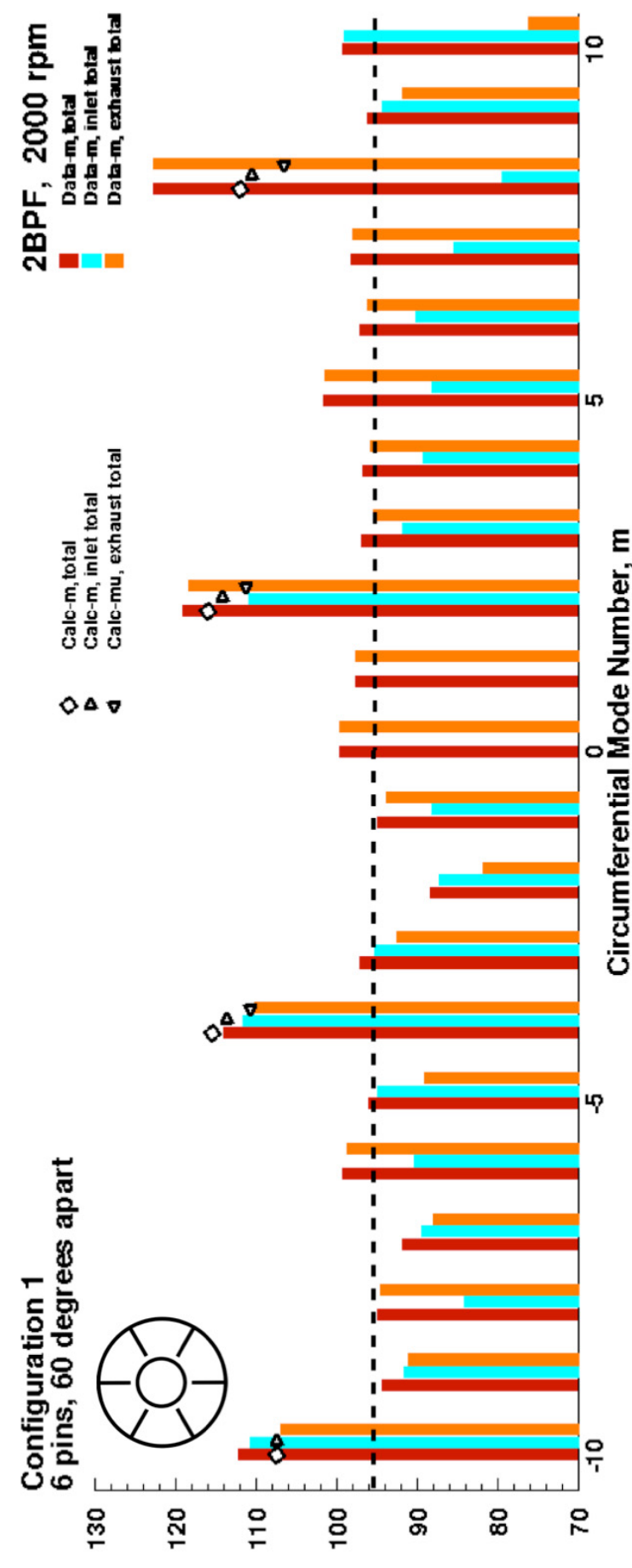

ap ‘әләך ләмод punos әроw
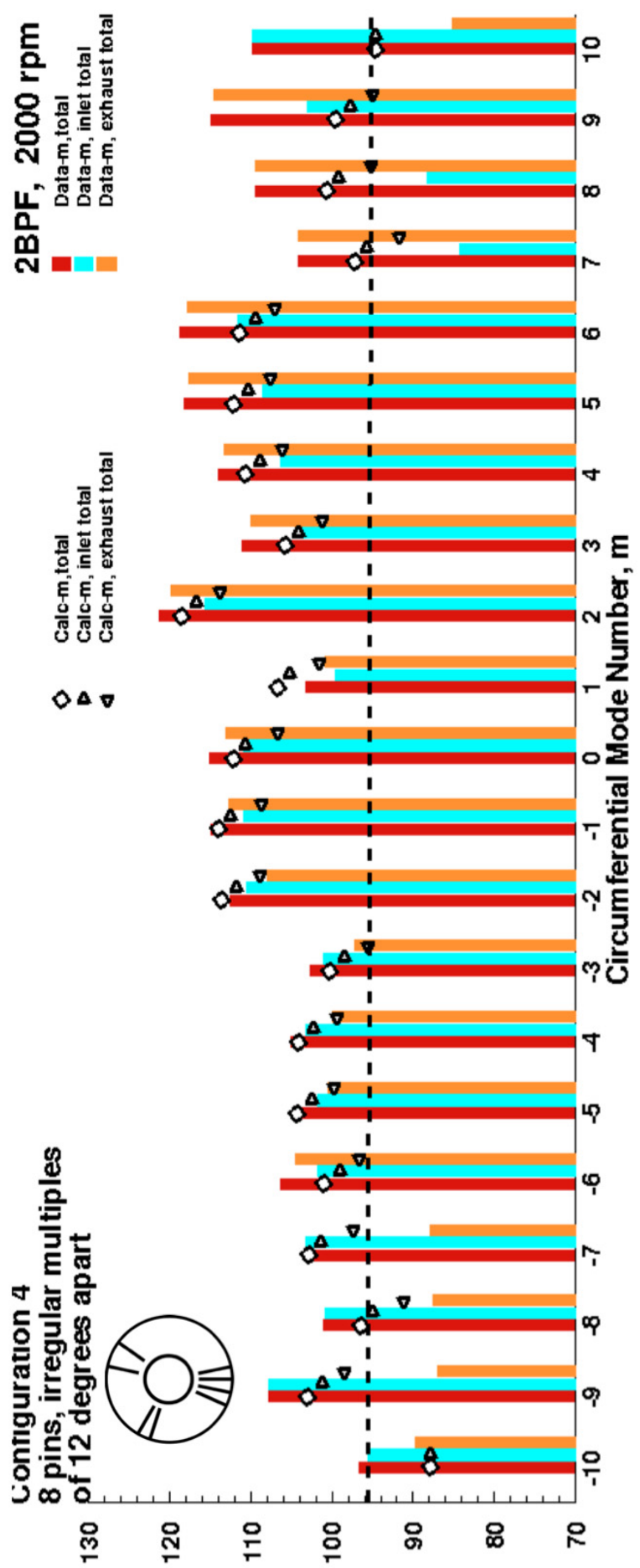

gp 'ןәләך גәMOd punos әpow

(a)

(b)

Figure 16.-Predicted and measured in-duct total, inlet-total, exhaust-total circumferential mode sound power levels for 2 BPF, $2000 \mathrm{rpm}$. Horizontal dotted line indicates the noise floor for the data set. Uncertainty in measured mode sound power levels is $\pm 2 \mathrm{~dB}$. (a) Configuration 1 (2007) and (b) Configuration 2 (2007). 


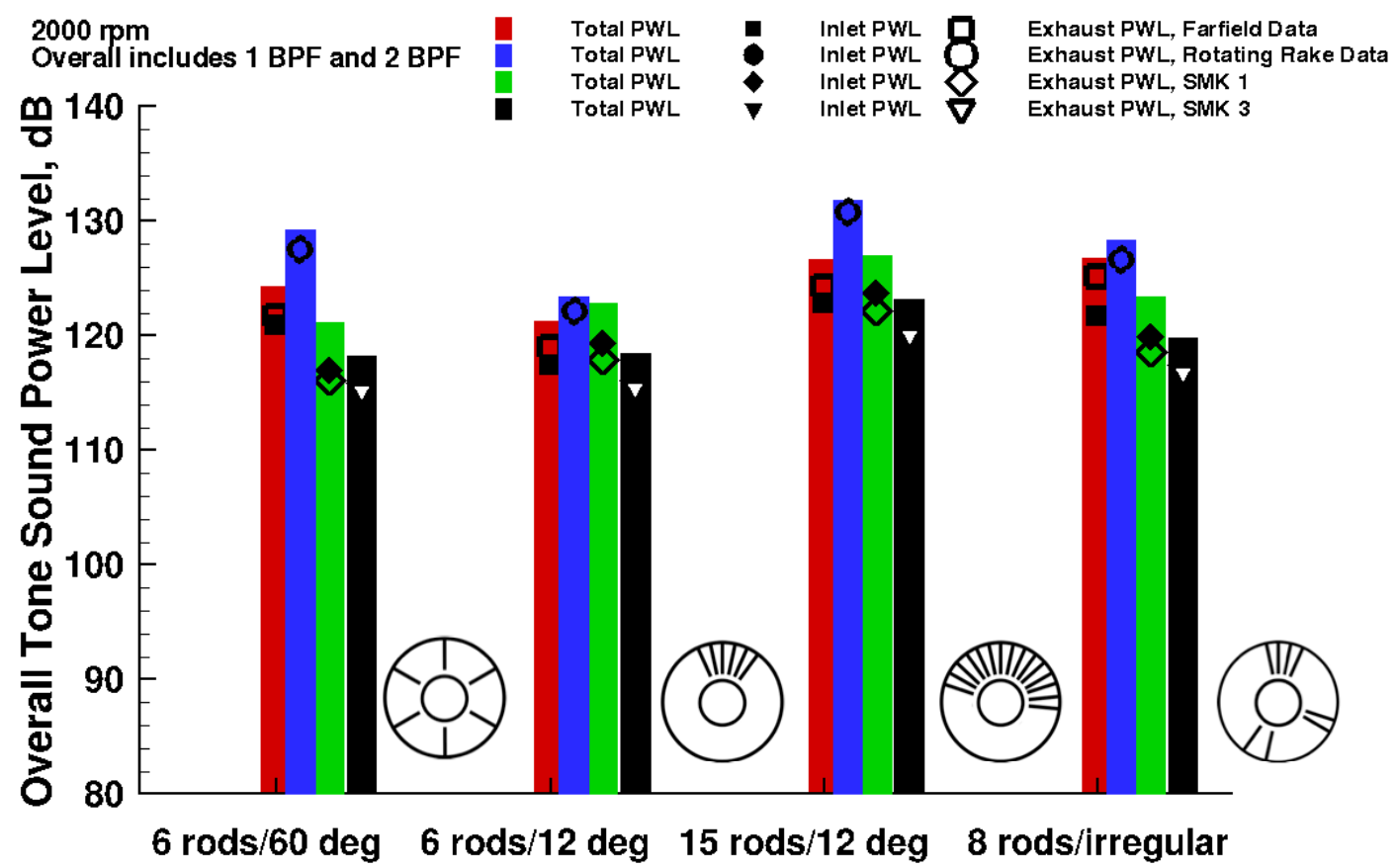

Figure 17.-Comparison of measured and predicted overall sound power levels for all 2007 configurations at $2000 \mathrm{rpm}$. Calculation of overall sound power levels includes contributions from the first two harmonics of the blade passing frequency tone only. Bars represent the total sound power levels, while the symbols indicate the sound power levels in the inlet and exhaust ducts.

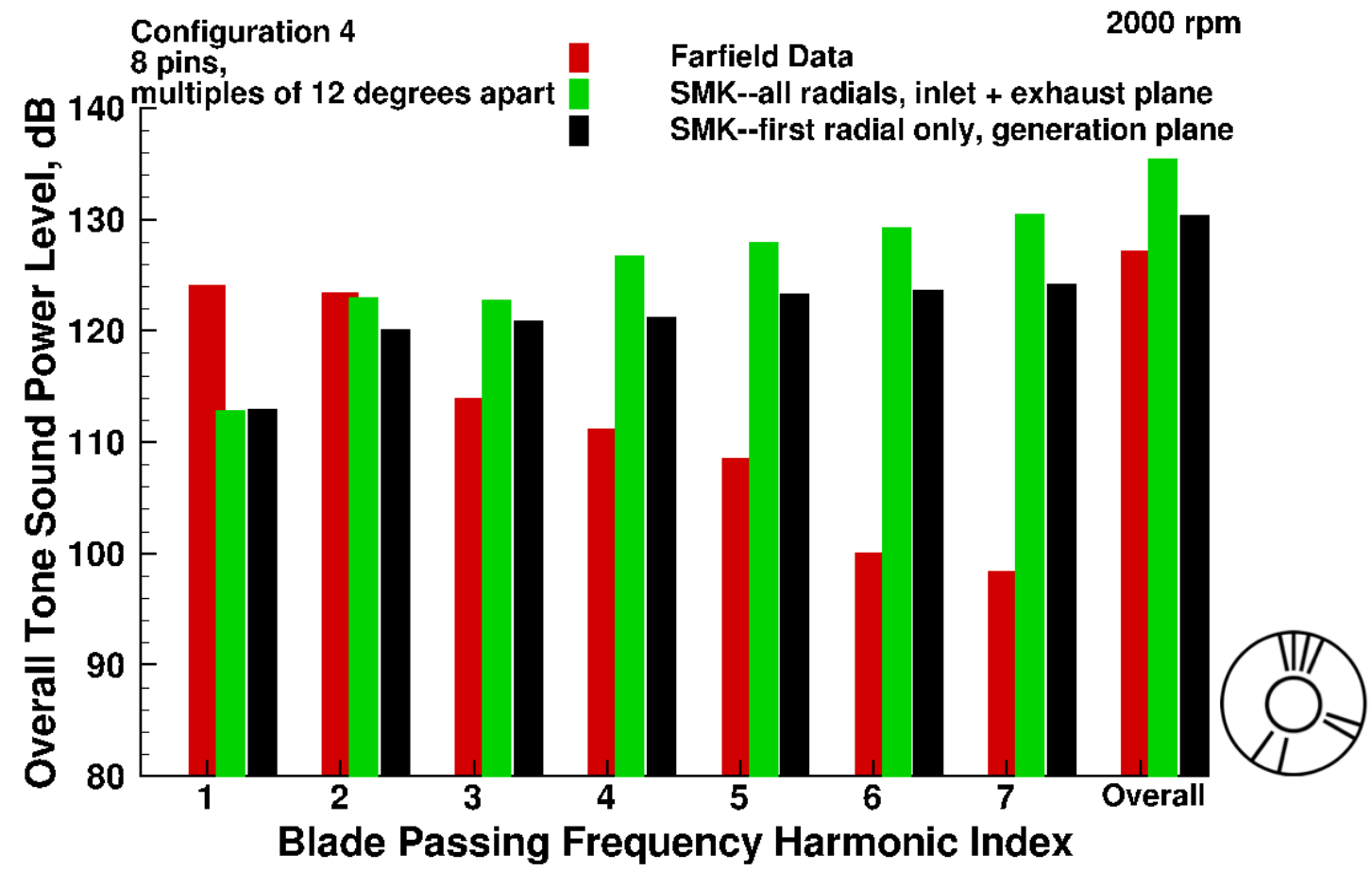

Figure 18.-Predicted overall sound power levels for Configuration 4 (2007) at $2000 \mathrm{rpm}$ compared to farfield microphone array measurements. Calculation of overall sound power levels includes contributions from the first seven harmonics of the blade passing frequency tone only. 


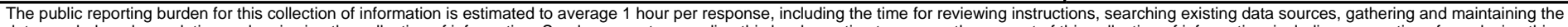

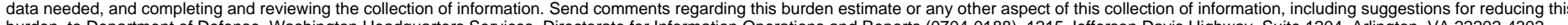

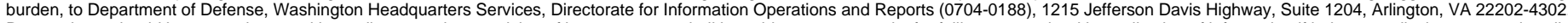

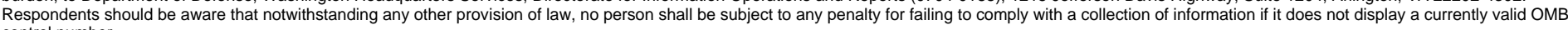

control number.
PLEASE DO NOT RETURN YOUR FORM TO THE ABOVE ADDRESS

\begin{tabular}{l|l|l}
\hline $\begin{array}{l}\text { 1. REPORT DATE }(D D-M M-Y Y Y Y) \\
01-02-2012\end{array}$ & $\begin{array}{l}\text { 2. REPORT TYPE } \\
\text { Technical Memorandum }\end{array}$ & 3. DATES COVERED (FrOm - To) \\
\hline
\end{tabular}

4. TITLE AND SUBTITLE

Validation of the Predicted Circumferential and Radial Mode Sound Power Levels in the Inlet and Exhaust Ducts of a Fan Ingesting Distorted Inflow

5a. CONTRACT NUMBER

5b. GRANT NUMBER

5c. PROGRAM ELEMENT NUMBER

6. AUTHOR(S)

Koch, L., Danielle

\section{5d. PROJECT NUMBER}

5e. TASK NUMBER

5f. WORK UNIT NUMBER

WBS 561581.02.08.03.18.11

7. PERFORMING ORGANIZATION NAME(S) AND ADDRESS(ES)

National Aeronautics and Space Administration

John H. Glenn Research Center at Lewis Field

Cleveland, Ohio 44135-3191

\section{SPONSORING/MONITORING AGENCY NAME(S) AND ADDRESS(ES)}

National Aeronautics and Space Administration

Washington, DC 20546-0001
8. PERFORMING ORGANIZATION REPORT NUMBER

E-18008

\section{DISTRIBUTIONIAVAILABILITY STATEMENT}

Unclassified-Unlimited

Subject Category: 71

Available electronically at http://www.sti.nasa.gov

This publication is available from the NASA Center for AeroSpace Information, 443-757-5802

\section{SUPPLEMENTARY NOTES}

\section{ABSTRACT}

Fan inflow distortion tone noise has been studied computationally and experimentally. Data from two experiments in the NASA Glenn Advanced Noise Control Fan rig have been used to validate acoustic predictions. The inflow to the fan was distorted by cylindrical rods inserted radially into the inlet duct one rotor chord length upstream of the fan. The rods were arranged in both symmetric and asymmetric circumferential patterns. In-duct and farfield sound pressure level measurements were recorded. It was discovered that for positive circumferential modes, measured circumferential mode sound power levels in the exhaust duct were greater than those in the inlet duct and for negative circumferential modes, measured total circumferential mode sound power levels in the exhaust were less than those in the inlet. Predicted trends in overall sound power level were proven to be useful in indentifying circumferentially asymmetric distortion patterns that reduce overall inlet distortion tone noise, as compared to symmetric arrangements of rods. Detailed comparisons between the measured and predicted radial mode sound power in the inlet and exhaust duct indicate limitations of the theory.

\section{SUBJECT TERMS}

Predicted circumferential; Radial; Mode sound; Fan

\begin{tabular}{|c|c|c|c|c|}
\hline \multicolumn{3}{|c|}{ 16. SECURITY CLASSIFICATION OF: } & \multirow{2}{*}{$\begin{array}{l}\text { 17. LIMITATION OF } \\
\text { ABSTRACT } \\
\text { UU }\end{array}$} & \multirow{2}{*}{$\begin{array}{l}\text { 18. NUMBER } \\
\text { OF } \\
\text { PAGES } \\
28\end{array}$} \\
\hline $\begin{array}{l}\text { a. REPORT } \\
U\end{array}$ & $\begin{array}{l}\text { b. ABSTRACT } \\
U\end{array}$ & $\begin{array}{l}\text { c. THIS } \\
\text { PAGE } \\
\text { U }\end{array}$ & & \\
\hline
\end{tabular}

\section{SPONSORING/MONITOR'S NASA}

11. SPONSORING/MONITORING REPORT NUMBER

NASA/TM-2012-217253 

